Article

\title{
Gender, Madness, Religion, and Iranian-American Identity: Observations on a 2006 Murder Trial in Williamsport, Pennsylvania
}

\author{
Camron Michael Amin \\ Department of Social Sciences-History, University of Michigan-Dearborn, 1270 SSB (Social Sciences Building), \\ 4901 Evergreen Rd, Dearborn, MI 48128, USA; camamin@umich.edu
}

Received: 12 June 2017; Accepted: 25 July 2017; Published: 1 August 2017

\begin{abstract}
Using participant observation, oral history interviews, and a study of court transcripts, Internet chats, and press coverage of a 2006 murder trial of an Iranian-American man in Williamsport, Pennsylvania, we can better appreciate the dynamic intersection of ethnicity, religion, and gender in constructing the social identity of Iranian-Americans. Brian Hosayn Yasipour, who immigrated to the United States in 1969, was convicted of murder in the third degree for killing his four-year-old daughter in 2001 during a custody dispute with his estranged, Iranian-born wife. He managed to avoid the death penalty. Debates about his guilt in America hinged on assessments of his mental state at the time of the crime and this, in turn, hinged on debates about how normative his actions would have been in Iran. Until his arrest, Brian had led a highly mobile life-moving back and forth between America, where he lived as a Christian, and Iran, where he visited as a Muslim. Was he a calculating Iranian-Islamic patriarch, outraged at the defiance of his wife and the attitudes of American courts toward his paternal rights? Or was he, per the court transcripts, a "white Christian" and survivor of childhood rape back in Iran, who lapsed into madness under the strain of his second divorce? Brian actively blurred these issues in court appearances before and after the murder-often expressing his agency in terms of preserving his imaginary and physical mobility.
\end{abstract}

Keywords: Iran; America; immigration; Muslim; filicide; gender; identity; mobility; Islamophobia; homophobia

\section{Introduction}

\subsection{Overview}

In this study I make use of a "regimes of im/mobility" approach (Schiller and Salazar 2013; Hackl et al. 2016) to analyze how ethnic identity, religious identity and gender ideology influenced the trial of an Iranian-American man in Williamsport, Pennsylvania for murder. Trial transcripts clearly illustrate how both the defense and prosecution exploited the ambiguity of Brian Yasipour's identity to bolster arguments for and against the proposition that Brian was legally insane at the time of the crime. But they also illustrate that Brian himself did not simply exist in a liminal state-not quite American, not quite Iranian — but deliberately moved between Iranian and American contexts both physically and conceptually from the time he arrived in the United States in 1969 until his arrest. He continued to assert his mobility conceptually while incarcerated, both before and after his conviction.

This study is also based on my observations as a pro bono consultant to pre-trial preparations of Brian's attorneys from 2004-2006, interviews with a number of participants conducted between 2010 and 2014, local media coverage, and the Internet postings of individuals who monitored the trial. These sources clearly illustrate the instability of the social categories applied to Brian Yasipour and his family by the Court and local community. The trial accomplished a sort of judicial assimilation 
of Brian. The verdict transformed him from an Iranian immigrant, who was free to move between Iranian/Muslim and (White) American/Christian contexts, into an American murderer who was confined to prison. The final judicial word on the case by the Superior Court of Pennsylvania in 2008 provided no indication that Brian's identity was ever an issue at trial. Brian's appeal was entirely focused on whether or not the Lycoming County Court had fairly accounted for evidence in his insanity defense (Superior Court of Pennsylvania 2008, para. 7-8). The words "Iran," "Iranian" or "immigrant" are nowhere to be found that final legal record. Taking a "regimes of im/mobility" approach to available sources restores to the narrative the fact that ethnicity, religion, and gender ideology were inextricably entwined in the trial process itself, despite being erased in the verdict and subsequent legal opinions.

\subsection{Structure of Article}

It is beyond the scope of this article to develop all of the lines of inquiry that might emerge from a detailed case study such as this one. Section 1.3 describes the evolving methodology of this study and considers it in relation to the genre of microhistory and studies of the "cultural defense" trial strategy used to insulate foreign-born defendants from criminal liability. It argues, however, that there are compelling analytic possibilities related to gender, ethnicity, and religion. Section 1.4 argues further that the interrelated nature of gender, ethnicity, and religion in this case is most usefully analyzed through a "regimes of im/mobility" approach. It also presents the important contexts provided by different prisms: Iranian-American Studies, Middle Eastern/Islamic Studies, Women and Gender Studies and studies of the phenomenon of filicide itself. Sections 2.1-2.3 apply the "regimes of im/mobilty" approach to illustrate how Brian's gender ideology, ethnicity and religion influenced assessments of his sanity, which, in turn were the key to assessing his guilt. Section 3 offers a concluding discussion of the implications of both the findings and limitations of this study for future research.

\subsection{Brian Killed Susan: Trial as Applied Microhistory}

Criminal trials, it should be noted, are unusual in the United States, and this was certainly the case in Pennsylvania. In a study of convictions of 12 different criminal offences from 1997 to 2000 in Pennsylvania, only 3.7\% (2537) of convictions were obtained by bench trial, and 2\% (1365) by jury trial. The remaining 63,899 convictions were the result of plea deals (King et al. 2005). So, for a historian, having a rich criminal trial transcript to examine is both a windfall and a challenge. Transcripts of trials have long served as an important source of social history. Beginning with the work of Ronald C. Jennings (Jennings 1999, for his collected works), studies of court records have had an enduring impact on Middle Eastern, Islamic and Women and Gender Studies (e.g., (Tucker 1998; Pierce 1999)). In Iranian Studies, fieldwork in contemporary Iranian family courts has catalogued not only patriarchal practices in the Islamic Republic of Iran but also women's resistance to such practices (Mir-Hosseini and Longinatto 2003; Osanloo 2006a, 2006b).

The genre of microhistory-the study of a discrete, short-term event as a microcosm of a wider social world-was arguably born with the close study of a trial record. Like Menocchio in Carlo Ginzburg's classic microhistory, The Cheese and the Worms: The Cosmos of a Sixteenth-Century Miller (Ginzburg 1980), much of what we know about Brian is through his interaction with a judicial process that put his idiosyncrasies into relief against other cultural norms. There are, of course, crucial and essential differences between the circumstances under study here and those taken on by Ginzburg. Menocchio's life was forfeit for articulating his beliefs-beliefs deemed heretical by a Catholic church in the midst of the brutalities and polemics of the Counter-Reformation. Brian's life was in jeopardy for a brutal act of murder. If Menocchio had recanted, his life would have been spared. Brian's crime, if proven, could not simply be excused.

Much ink has been spilled, including by its practitioners, to define microhistory to everyone's satisfaction (Brown 2003; Findlen 2003, 2005; Ginzburg et al. 1993; Ginzburg 2005; Lamoreaux 2006; Lapore 2001; Putnam 2006; Ze'evi 1998). How is it different from biography or closely descriptive 
field notes? Why lose the historically significant "forests" amidst close study of local or short-lived "trees?" How might a microhistorical approach be applied in this or that subfield of history? For me, microhistory is the closest description of the result of my evolving research methodology. Brian Yasipour's trial was "exceptional typical" — to follow Matti Peltonen (Peltonen 2001). The most essential sources - the trial transcript and interviews-were "local" and form an inherit limit on the focus of study. At the same time, they are connected to a wider socio-cultural order and raise issues that are part of broader academic conversations-too many to elaborate upon equally within the scope of this article (See Section 1.4).

One reason we have such a rich transcript in this case is because up until a month before the trial, it was set to be a death penalty case tried before a jury. Both sides had spent years preparing for that eventuality. Then, on 22 February 2006, the prosecution agreed to drop the death penalty in exchange for a bench trial. Yet, they proceeded initially with what they had prepared for a jury trial. Stephanie Farr, then of the Williamsport Sun-Gazette, covered the trial. She wrote, "Although it was not necessary ... the defense and prosecution opted to present opening statements to county Judge Dudley N. Anderson, the presiding judge in the bench-trial case (Farr 2006a)." For two days, calling on 22 witnesses, the prosecution laid out its case in exhaustive detail (YT, March 6th and 7th). "A class of junior and senior students from Montoursville High School who attended the trial on Monday were surprised by the monotony of the proceedings but more so by the photographs of young Susan ... 'The stuff on TV looks fake now,' Dawn Bennett, 18, of Montoursville said (Farr 2006a)."

The prosecution's theory of the case depended on a particular narrative of the day of the murder-an applied microhistory, if you will, built upon the testimony of police officers and forensic experts and eyewitnesses to a few key events in the days leading up to the murder. What follows is a summary of that applied microhistory, reflecting facts of the case that were not contested by the defense in the first two days of the trial. Brian killed Susan-of this, there is no doubt:

He attacked her in an upstairs bedroom of a shabby green house on 1024 Memorial Drive in Williamsport, Pennsylvania. After sixty knife wounds, sometime between 4:00 and 4:30 p.m. on 24 August 2001, Susan succumbed. The coroner could not tell which wound killed her, but she could tell that Susan had tried to defend herself. She had no real chance of surviving the brutal attack. Brian was 52 and little Susan had not yet turned five. Her birthday was but three days away.

After killing her, Brian checked the street. He went to a nearby Bi-Lo store and bought flowers. He came back and washed her clothes; he washed her body. He placed her back into bed and surrounded her with the flowers and with her favorite stuffed animals. He washed the two knives that he had used to kill her. They were his knives. This was his house. Susan was his daughter.

At 7:15 p.m., a missionary stopped by the house. Brian sent him away saying it wasn't a good time. At 7:20 p.m., he went out to a dumpster and threw out some pornographic videotapes. At 7:25 p.m., Brian called 911 to report that he had found Susan dead. Police arrived at 7:27 p.m., and it was not long before Brian was taken into custody. He cooperated with police; he even helped them find Susan's mother, Amaneh, known in Williamsport as Mellie. She would be at the McDonald's on East 3rd, across from the Learning Works. Mellie and Brian were legally separated and just coming to the end of a long and bitter custody battle over Susan. That morning, Brian's visitation was reduced so that Susan could attend kindergarten. Brian was supposed to hand Susan back over to Mellie at the McDonald's at 8:00 p.m. that evening.

At the police station, officers tried to build on Brian's cooperative behavior and coax a confession from him. He sobbed, looking at a picture of his daughter. For a while he maintained that he had found Susan after going to the Bi-Lo store to buy flowers. She looked scared, he said, so he had cleaned her up and placed her in his bed in new clothes, 
and with the stuffed animals and the flowers he had bought. He complained that he was hungry (and a diabetic), so an officer was sent to McDonald's. There, Mellie approached the officer. Brian had done this before-been late with Susan. Once before, in fact, he had kidnapped her. The week before Brian had followed Mellie and Susan from the McDonald's to the Learning Works and had threatened Mellie (but not Susan). Because of the way a custody hearing had gone earlier that day, she was worried that Brian had kidnapped Susan again. He had lost some of his visitation time so that Susan could start kindergarten in September, but she had agreed to let Brian have Susan for the afternoon following the hearing. Kidnapping was likely the worst thing Mellie could imagine Brian doing in response. Almost no one who testified-and certainly no one who knew the family well-had imagined Brian could do this.

The trial focused on the day of the murder, but it also examined many aspects of Brian's life before the trial (See Table A1 in Appendix A). For all that detail, it also left some information out of the discussion completely. Brian had not just sobbed at the sight of his daughter's photograph. Later that night he had confessed. Because Brian had not been properly Mirandized on the night of his arrest, Judge Anderson ruled his confession inadmissible on 22 November 2002 (Anderson 2002). All of the attorneys present at court in March 2006 and, of course, Judge Anderson himself, were aware of the confession but did not present it in open court or debate in any recorded sidebar in Judge Anderson's chambers. I, as a consultant to the defense, was not aware of the confession at the time. But since a record of it exists as part of the 22 November ruling, Brian's confession can be included in this analysis (Section 2.3).

Winning the motion to suppress Brian's confession was an important victory in the pre-trial period for his attorneys provided by the Public Defender's office, William Miele and Nicole Spring. Given the physical and circumstantial evidence, however, they also knew that the facts of the case would not exonerate Brian. "We ruled out self-defense pretty quick," Miele quipped. They were, of course, horrified by the crime but also obligated to provide a defense for Brian. Brian's history of mental illness would be crucial in defending his life, not his actions on 24 August. Miele had been worried about a jury trial, "for two reasons: one was the victim and the other was his nationality. Because this is a small, conservative, narrow-minded community." Nicole Spring added, "Any kind of Middle Eastern (background). The fear being that he killed a female child and is that going to be 'Okay, he thinks he has the right to' (Miele and Spring 2010, Time Index 7:38-8:28)?" Furthermore, Miele and Spring became aware of the prosecution's plan to use Brian's own words to help play to those biases and to undermine Brian's insanity defense. Prosecutor Michael Dinges was going to argue that Brian killed Susan in accordance with Iranian patriarchal norms. So, as part of preparations for what they assumed would be an inevitable "penalty phase" of the trial, they recruited me as a "cultural expert" on Iran to argue that Brian's actions would not, in fact, be considered "normal" in Iran. Rather, they intended to argue, Iran was the place where Brian's mental troubles began with the trauma of being raped by an older boy when he was twelve. I served in that role pro bono from late 2004 until the trial's conclusion in 2006 and, therefore, participated in the crafting of the hybrid cultural-insanity defense to counter the "cultural prosecution" Brian faced.

I raise these two issues here to highlight the essential methodological challenge of this study: I did not participate in the trial with the intent of observing it for academic study. But, as the trial date approached and I caught more glimpses of how the defense team was managing the issue of Brian's identity using my input about Iranian history and society, I resolved to reflect on what was happening as soon as the case reached its legal conclusion; this turned out to be the Superior Court of Pennsylvania's rejection of Brian's last appeal in 2008. With some funding from my campus, I ordered the full trial transcript (approximately 1200 pages, double-spaced) and traveled to Williamsport twice in 2010 to interview key participants. The transcripts were supplemented with several other court opinions on the case made available by the Lycoming Law Association (http:/ / www.lycolaw.org). 
I also revisited media coverage of the trial. My first impression of the local media coverage happened during the trial. This is because shortly before the trial, the defense team decided that the report I wrote for the Court would be sufficient and that it was unlikely that I would be called to testify about it. So, I did not attend the trial itself. As the trial progressed, they became less sure of that decision and wanted me to be available to testify by phone. So, each day during the trial, I scoured the Internet for glimpses of media coverage to supplement the brief updates I received from Miele and Spring. The most thorough coverage came from the Williamsport Sun-Gazette. But my search turned up something more: an active discussion on a web forum called Forums for Justice. Participants in this particular form of "non-institutional" media coverage of crime (Wheeler 2008) seem to obsess over abduction and murder cases - that of JonBenet Ramsey, in particular, with posts continuing to the time of writing. Two individuals dominated the five pages of posts on the "Yasipour thread" from 7 March to 19 April 2006: "Quinn" and "LurkerXIV." Quinn attended the trial and re-posted Williamsport Sun-Gazette coverage. In 2014, I had an opportunity to interview Stephanie Farr about her time covering the trial; she had not been aware of the FFJ discussions. At times, the substance of the virtual dialogue between Quinn and LurkerXIV epitomized the Islamophobic bias that Miele and Spring were afraid might exist in a local jury pool. But, as we shall see, their engagement with the Yasipours was more complicated than that.

In addition to the genre of microhistory, there was another academic prism through which I reflected upon this case: studies of "cultural defense." Volpp (2012) notes that the state employs metaphors about the legally imagined space of the homeland; these metaphors can change in accordance with attitudes about immigrants to support rulings against the interests of "non-White" immigrants and refugees. She also points out that both domestic and international legal orders divide the world into "failed states" with "pathological cultures," whose calling card is violence against women, versus (Western) states with functioning civil societies and "a monopoly on legitimate violence (Volpp 2006)." The prosecution's case might be thought of as an attempt to portray Brian as a typical product of a pathological foreign culture. In this reading his hyper-patriarchal gender ideology would have nothing to do with his damaged psyche. Instead, it was marker of his foreign-ness. A study of "cultural defense" in Belgium notes how it can be seen as a kind of performance in which a defense attorney actually emphasizes the foreignness of a client so that the jury will see the client's attorney as part of their society and be more receptive to the defense's argument (D'hondt 2010). A similar dynamic was evident in the transcript of the sidebar in Judge Anderson's chambers discussed in Section 2.2. Miele emphasized Brian's Iranian Muslim roots every bit as much as District Attorney Dinges, but to a different end: portraying Brian as the victim of a pathological culture. For the most part though, academic studies of "cultural defense" rest on close readings of legal opinions and related academic and journalistic commentary (For examples, see (Levine 2003; Demian 2008; Sharafi 2008)). The researchers in this field do not often engage with the participants in trials. They focus on case studies to examine the efficacy and policy consequences of cultural defenses. The only large-scale and long-term study of "cultural defenses" seems to have been undertaken in Israel. That study found that, in addition to the phenomenon of cultural defense, there were also many instances of cultural "offense" where convicts received harsher sentences because of their perceived difference from the dominant culture (Tomer-Fishman 2010). Furthermore, the most common reaction to cultural factors was to ignore or discount them. This is very much what happened, at the end of day, with Judge Anderson's verdict: the cultural offense and defense cancelled each other out to highlight "the science," in Judge Anderson's words (TY 2006, p. 136, 21 March), of expert psychological testimony.

Nevertheless, transcripts and press coverage of the trial illustrate that discussions of Brian's ethnicity, religion and gender ideology were entwined with debates over his sanity. And the question of his sanity was essential to his conviction. Brian's identities as an Iranian immigrant, as a convert from Islam to Christianity, and as a person afflicted by mental and physical illness were not overlooked or ignored by Judge Anderson. The microhistory of the process of judicial assimilation is lost in the final verdict, but preserved in all the sources being marshaled here. And there is another fact 
that emerges from those sources: Brian was not a passive recipient of this judicial assimilation. His agency was often expressed in terms of his mobility between Iranian and American culture. Just as it would be possible to consider the history of this trial entirely within the scholarly conversations about microhistory and "cultural defense," it would be possible to consider it within the subfields of Iranian Studies, Middle Eastern/Islamic Studies, Iranian-American Studies and Women and Gender Studies. However, the "regimes of im/mobility" approach allows us to benefit from the insights of those fields while permitting us to appreciate the dynamic way in which these insights would resonate with what participants did at the time and how they viewed the trial in retrospect.

\subsection{Im/Mobilities as an Analytical Framework: Navigating the Intersection of Gender Ideology, Ethnicity, and Religion}

Let's briefly consider some other academic conversations in which we might situate the history of this trial, beginning with the sub-field of Iranian-American/Diaspora Studies. The extraordinary circumstances here are precisely what make it challenging as "exceptional typical." Aside from the tragedy itself, there are other contrasts between Brian and the "typical" Iranian-American assimilation narrative. For example, the Yasipours do not seem to be well off financially in 2000, at a time when per capita income of Iranian-Americans was estimated to be more than 38\% higher than for native-born Americans (Public Affairs Alliance of Iranian Americans 2014, Iranian Americans: Immigration and Assimilation, p. 12). Also, the Yasipours did not live in one of the states with a large concentration of Iranian-Americans: New York, Texas, Maryland, California, Virginia, Florida, Washington, D.C, and Georgia. Pennsylvania was estimated to have had a population of "foreign-born Iranians" of 2129 in 1990 and a population of "Iranian descent" of 4657 ca. 2000 (Fata and Rafii 2003, p. 11; Modarres 1998, p. 41). There was no Iranian enclave in Williamsport, and the Yasipours attended a church in nearby Montoursville.

It is difficult to score Brian's circumstances with the classic measures of assimilation, which are problematic in any case (Walters and Jimenez 2005; Alba and Roe 1997; Mostofi 2003). The rate of marriage outside of one's group is one such measure, with one Iranian-American advocacy group claiming it "to be estimated" at 50\% (Public Affairs Alliance of Iranian Americans 2014, Iranian Americans: Immigration and Assimilation, p. 11). Aside from any skepticism about that estimate, was Brian's first marriage to American-born Betty Keller the one that should count toward this metric or his second marriage to the Iranian-born Amaneh/Mellie? Even the consideration of socioeconomic success - a metric to which Iranian American advocacy groups proudly point-is hard to resolve. Was Brian a more representative Iranian-American when he was a successful life insurance salesman in the 1980s, when he was disabled by mental illness in the 1990s, or when he was convicted of murder? The ephemeral position Brian occupied with respect to such analytical categories during his life does not invalidate those categories, of course. Nevertheless, it serves to remind us how much an individual's or a family's social standing can fluctuate relative to any group norm we may wish to deploy analytically.

When Judge Anderson and William Miele debate whether Brian should be fairly considered a "White Christian," this does touch on something that has been the subject of scholarly investigation in Arab-American Studies (Gualtieri 2009, especially pp. 52-80) and Iranian-American Studies, which examine the history of Middle Eastern immigrants attempting to assimilate "through the ultimate prize of White recognition ((Tehranian 2008, p. 1235); see also (Tehranian 2009))." A forthcoming study of "whiteness" by Neda Maghbouleh emphasizes the "instability" of that category in the identity of Iranian-Americans (Code Switch 2017, April 19, Time Index: 10:29-18:41), and that is certainly evident in the case of Brian Yasipour. Furthermore, it is not as though modern Iranian national identity itself has not also been subject to racialization (Zia-Ebrahimi 2016) or that Iranian society was immune from racist traditions of its own. Iranian visitors and immigrants could (and can) be alert to racism in America without reflecting on their own attitudes. For example, visiting the United States in 1945, the editor of Iran's main daily newspaper expressed shock at the Ku Klux Klan while also offering his own racist descriptions of minority neighborhoods in New York (Amin 2014, p. 171). In this case, 
however, the sources do not grant direct insight into whether the Yasipours thought of themselves as "white" or in racial terms at all.

And, as we shall see in Section 2.1, religion was a more visible component of Brian's presentation of his ethnicity in court. Brian did not just invoke Iranian ethnicity to remove himself imaginatively from American legal jurisdiction, but Islamic law and a highly patriarchal reading of Islamic/Iranian family norms. What the literature on Women and Gender Studies within Islamic Studies offers us is clarity on just how idiosyncratic and reductive Brian's expressed views on his "heritage culture" were. Iranian legal culture has been a hybrid system of European and Islamic jurisprudence for decades, no less dynamic than the American legal culture in which he was being tried. This point will be revisited in greater detail in Section 2.1.

Even if we were to ignore the Iranian/Muslim aspects of this story, it would be hard to describe this tragedy as typically "American" or representative of the filicide phenomenon in the USA or around the world. Based on a study of U.S. arrest records from 1976 to 2007, 15\% of all homicides can be classified as filicide (involving victims of all ages). Mothers and fathers were equally likely to kill sons and daughters who are between the ages of one and 17 ( $3 / 4$ of victims were under the age of 6). Only $5.5 \%$ of filicidal parents used "edged weapons" (including knives), compared with $49.2 \%$ using their bodies (e.g., fists) as weapons and $23.3 \%$ using firearms. Most alleged offenders arrested were white (the category to which Brian was classified). At age 52, Brian was among the $15.1 \%$ of alleged offenders in the USA aged between 41 and 60 years (Mariano et al. 2014). Researchers are still uncertain of the predictive value of known risk factors such as history of abuse, mental illness, family discord, and substance abuse to filicide. It is very difficult to predict and prevent filicidal ideation and action. Brian was in and out of family court for almost two decades before Susan's murder, but all who knew him were blindsided. For all his litigious and difficult behavior, Brian had no prior history of violence. Furthermore, per a Finnish study, the only certain way to prevent a filicidal parent from acting (on impulse or in some deliberate way) is to deny the parent access to the child (Lehti et al. 2012, p. 16). What is hard to predict is also hard to understand in retrospect. Simply constructing a new narrative with these prisms in mind will miss something important: the "real-time" fluidity and instability of Brian's social identity. Brian's assertions of different social identities and the variable ways in which he and his family were perceived during the trial rested on interrelated markers of their "otherness:" gender ideology, ethnicity and religion. A "regimes of im/mobility" approach can help us trace how different aspects of Brian's identity became visible and salient over the course of events and influenced the final verdict.

In formulating their "regimes of im/mobility" approach to the study of migration and transnationalism, Schiller and Salazar (Schiller and Salazar 2013) encourage a multi-faceted analysis. Analyses should try and account for individual agency in relation to "unequal globe-spanning relationships of power," as well as the "unequal relationalities" of local contexts, state actors, and class that can operate on an individual's mobility-facilitating it, restraining it (to the point of stasis) and interpreting it in a given contemporary moment, as well in historical context (Schiller and Salazar 2013, p. 200). With this 2006 trial in Williamsport we have a specific historical context with a lot of documentation relating to the actions of an individual. It involved a very high-stakes decision about that individual's mobility (imprisonment/execution versus death). And although there was never a doubt that the primary legal context would be local and "American," there was a lot of doubt about whether Brian was fully a member of that local American context and if some consideration should be given to a "foreign" cultural context in determining his guilt or innocence. Hackl argues in Bounded Mobilities (Hackl et al. 2016) for the need to move beyond the material manifestations of mobility to the conceptual. This is to bring into focus the interplay between identity and boundaries, the dynamics of imaginary, virtual and gendered $\mathrm{im} / \mathrm{mobilities}$ and diverse combinations of mobility and immobility that can affect both the most confined and the most "hypermobile" individuals and groups (Hackl et al. 2016, pp. 19-34). As we shall see, on the conceptual level, Brian was "hypermobile" - moving back and forth between imaginary 
Iranian/Muslim and American/Christian contexts. But, it was not just a flight of fancy on his part. Prior to his arrest he had moved back and forth between Iranian and American contexts. All this made assessments of his "true" cultural home by others more fluid also. The "interplay" between identity and boundaries in this case was almost entirely conceptual (as the crime and trial took place in Williamsport). That interplay comes into view most clearly through interrelated discussions of Brian's gender ideology (and whether his obsessive patriarchal outlook was "normal" in Iran), ethnicity (where the use of Persian serves as additional marker of his "otherness"), and religion (where Islam is "Iranian" and Christianity is "white" and American).

The most consistent feature of Brian's agency was his insistence on mobility-physical and cultural-between Iran and America. The trial process depended, in part, on deciding between competing implications of Brian's mobility. According to his defense attorneys, he could never fully abandon his Iranian origins or the trauma of childhood rape that he suffered there. According to the prosecution, he would never fully abandon his Iranian origins-particularly its uncompromising patriarchy-because it justified in his mind what he did to his daughter. In both legal arguments, a reductively Islamic and Iranian culture was not confined to another place. Iran was either where Brian made sense or it was the root of his madness even when his was in Williamsport. In both depictions, "Iran" formed a boundary around Brian's "American-ness." This was much less the case for his victims, his family.

State actors (the judicial and public health system in Williamsport) and societal actors (the Williamsport community, the press, and the public that followed the case online) acted to punish Brian, support Mellie, and memorialize Susan. Each of these actions had real and symbolic immobilizing aspects, finally assigning them into a local American context. For Brian, ultimately, this meant prison. For Mellie, it was acts of generosity such as a local church donating a plot for Susan's burial and Susan's inclusion in a local memorial for victims of child abuse. Mellie and Susan are never discussed as anything other than natives of Williamsport-they became conceptually fixed in that locality. There are two reasons this is important. First, Mellie's immigration to the United States depended on her relationship to Brian. As their relationship deteriorated, she needed the protection of the state and the support of the local Williamsport community to escape from him. Testimony regarding a bi-lingual confrontation between Mellie and Brian a week before Susan's murder highlights the unraveling of a "gendered immobility" in which women's mobility can depend on acts of "gender-related bargaining over their status, including the 'microphysics of domestic power' usually held by male householders (Bonfanti 2016, pp. 183-208, in (Hackl et al. 2016, pp. 30))." Second, it underscores the fact that the conceptual and imaginary aspects of $\mathrm{im} / \mathrm{mobility}$ are at least as important as physical im/mobility in understanding the assimilative effects of the trial. No matter how it is discussed, "Iran" is only ever an idea that is invoked by state and individual actors to explain events that took place in America.

The most visible "state actor" in this analysis is the court system, as seen through court records and interviews with participants other than myself. And certainly my participation from 2004 to 2006 did limit my access to some of the other participants after the fact, notably the prosecutors, Michael Dinges and Kenneth Osokow. Accordingly, it was not possible to develop this analysis as a fully realized oral history, in which the recollections of all key individuals are analyzed in comparison with each other and other evidence. For the most part, though, my participation facilitated my access to information and people. The most visible individual actor in the study is Brian. My ability to interview Brian and reflect on accounts of his confession (in Section 2.3) provided evidence that is crucial to understanding how central mobility was in informing his actions, and, how concepts of mobility were entwined with Brian's transformation from an Iranian immigrant into an American murderer. The $\mathrm{im} /$ mobilities framework cannot and does not help explain every aspect of this narrative, but it does help us navigate the interrelated effects of gender ideology, ethnicity, and religion on the unfolding of this tragedy. 


\section{From Iranian Immigrant to American Murderer}

The following three subsections discuss im/mobility with respect to gender, ethnicity and religion in turn. However, because gender, ethnicity and religion are interrelated in the sources they remain interrelated in the three discussions. Sections 2.1 and 2.2 analyze events that took place during the trial or were discussed during at trial (though not always in open court). Section 2.3 analyzes events and discussions that happened outside the courtroom but were closely connected to the trial process as it unfolded or in retrospect. These events and discussions informed the process of Brian's conviction even though they are absent from the verdict in 2006 and in subsequent legal opinions on the case.

\subsection{Gendered Im/Mobility between Iranian and American Legal Systems}

In 2002, Mellie had sued to finalize her divorce from Brian as he awaited trial for Susan's murder. In the course of court proceedings to bifurcate the marriage on 10 December, Brian said this:

I am contesting the divorce because I do not believe in divorce, okay, and if she wants to get it, I have written her a letter. She has to go through proper channels [in Iran] to get it. Muslim marriage is not a sacrament but a simple legal agreement in which either party is free to [include] conditions. It's not a sacrament, so it's like a prenuptial agreement. I have another one [i.e., Iranian law in translation] from the Library of Congress. If you kill your child, you will not be charged. I can let you read it. It is in English. Okay, that's the law. If you like it or not. If a father, not a mother, if a father or grandfather or the father's side kill the child, you have to pay like $\$ 5000$ to the mother, but you can't be charged. That's the law, you know, that - we are really family oriented back there (Yasipour vs. Yasipour, 10 December 2002 cited in (TY 2006, pp. 142-43, 7 March). Emphasis added.).

Brian's 2002 courtroom declaration became the centerpiece of the District Attorney Michael Dinges' case against Brian-a window on his motivation for killing Susan. Dinges could point to other facts and circumstances. The day of the murder Brian had lost some of his visitation privileges and had been effectively barred by Judge Nancy Butts from further legal action. Yet, he was able to use the possibility of granting Mellie a divorce to negotiate access to Susan on that afternoon even though it was not his turn to have her. Not only had he tried to cover up the crime by tampering with the scene, but he also had several thousand dollars in cash at the time of his arrest, consistent, they argued, with the intent to flee. To where? Iran — the place where Brian had opined-incorrectly_ "If you kill your child you will not be charged." In 2002, Brian was asserting a kind of magical extraterritoriality that invoked two aspects of Islamic law-Iran's marital laws and criminal code at the time of the crime-in defense of his of marital rights under American law. In Brian's mind, the stigma of divorce in America would jeopardize his standing in Iran. This point was emphasized in the 2006 testimony of David Irwin, who represented Mellie in the 2002 divorce hearing:

[Brian] didn't necessarily testify. He sort of made a speech. The speech repeatedly went into the fact that under Iranian law the parties are married pursuant to a contract between them, and talked about it being a multiple page contract with all of the contingencies and that the [American] Court didn't have jurisdiction over them under Iranian laws because they can't undo the contract. He said that repeatedly. He also said something to the effect, and I will paraphrase here, that if the Court in America were to grant the divorce and his wife were to remarry, that if he went to Iran he would be teased or harassed, or something along that line. He spoke for, it seemed, quite a long time about that. He was very coherent and clear in his position. The judge then made his ruling and made it clear that under American law that things are different and the elements to bifurcate the divorce are present. I think, if I recall, Mr. Yasipour thanked him when it was over. (TY 2006, pp. 136-37, 7 March) 
Brian's representation of Iran's "family orientation" was hyper-patriarchal to the point of excusing paternal filicide and preserving male prerogatives in initiating divorce in Iranian law, which was governed by Twelver Shicite Islamic jurisprudence. In rebuttal to this cultural prosecution Brian's attorneys argued that Brian was wrong about Iranian law. But it is important to understand that they were pushing back against an argument by the prosecution that also reductively portrayed Iranian and American cultures as irreconcilably different. The courtroom debates about Brian's true "cultural home" conceptually restricted Brian's efforts to move back and forth between Iran and America at will for his own benefit. Brian's transcultural mobility was not just conceptual. In fact, he had been utilizing it ever since he settled in the United States. He was well-established in Williamsport and well-known in the local courts. This was underscored early in the pre-trial process when Brian unsuccessfully petitioned Judge Anderson to recuse himself on 31 August 2001. Though it was just six days after Susan's death, Brian recalled with rancorous bravado that Anderson had represented his first wife, Betty, in 1989: "I remember that day very well that you were yelling 'Mr. Yasipour pay your child support, you have recent inheritance [emphasis added] ... (Anderson 2001, pp. 3-4).'” The only way Brian could have inherited from his Muslim family in Iran is if he was thought to be Muslim in Iran. Did Brian present himself differently when he lived in America after 1969 to how he presented himself when he visited Iran?

On 11 June 2010, I had an opportunity to ask Brian about this. "Are you a Muslim in Iran and a Christian in America?" I asked. "Yes," he said. Whether due to the stroke or the anti-depressants he was prescribed, Brian's face and voice were largely emotionless, but not cold, subdued, or robotic. There would be, at times, the faintest bit of urgency in his voice as he sought to clarify a point.

"If you were on Mars would you be a Christian or a Muslim?" I asked.

"Christian."

"What did you like about Christianity?"

"Love your neighbor."

A number of studies have shown that Iranian-Americans of Muslim origin tend to be either less committed to Islam ("spiritual," agnostic, or atheist or otherwise affiliated) or, to a lesser extent, to take the step of converting to some denomination of Christianity (Chaichian 1997; Mobasher 2012). What is unusual here, beyond the fact that Brian converted while still in Iran in 1968, was Brian's insistence on the advantages he perceived in Iranian law and society while simultaneously insisting on the advantages of living as a naturalized American and Christian convert in 2002. District Attorney Dinges was, in effect, calling his cultural bluff in 2006. Judge Anderson, however, did not take Brian's assertions about Iranian law at face value. He said, "I have trouble believing that any even third world country would have a law that says, 'Okay, you can buy your way into and out of murders of your children.' ... I kind of accept that is not the law of Iran (Emphasis added. (TY 2006, 21 March, pp. 7-8)." Anderson's intuition was correct. The Iranian legal system that Brian was attempting to conjure in defense of his marital rights and his legal culpability for Susan's death was not trapped in some patriarchal, "family-oriented" amber. It had been changing in the face of modern, globalizing cultural forces.

In 2001, Mohammad Eshaqi published a treatise on filicide in Iranian law that was a call for reform framed around equal punishment for fathers and mothers. The proposed reform was presented as both a defense of Islamic legal norms and of "dynamic jurisprudence" (feqh-e puya) in Twelver Shi ism that is an Islamic Republican answer to pre-1979 legal reform in Iran. Eshaqi argued that all schools of Islamic law traditionally excluded filicide committed by fathers from qeșās (retaliation, i.e., the death penalty administered by the state on behalf of families who chose not to forgive the convict). Thus, filicide was outside the realm of hadd (required Koranic) punishments for crimes, and fell into the much larger realm of "discretionary" punishments, $t a^{\prime} z i$, which have typically constituted the bulk of the criminal code in countries observing Islamic law. 
In the Islamic Republic of Iran in 2001, filicide fell under Article 202 of the ta'zir criminal code. The question for Eshaqi was not whether the punishment was just but whether Article 202 could be revised to clarify that it would be applied equally to mothers and fathers who kill their children:

[Current Article 202]: The father or grandfather that kills his own child should not be subject to qesās, yet shall pay a diyeh ("blood money") to the heirs of the victim and be subject to $t a$ 'zir (3-10 years for "intentional murder").

Proposed revision:

The father or grandfather or mother or grandmother that kills their own child shall not be subject to qesās, yet shall pay the murder diyeh to the heirs of the victim and be subject to ta'zir. (Eshaqi 2001, p. 194)

Comparing Iranian law to British law, Eshaqi noted that "diminished capacity" (particularly its presumption in the case of mothers and the infanticide of children under 12 months) in British law is the functional equivalent of excusing parents from qesās in Islamic jurisprudence. In Eshaqi's view, the consensus opinion of Islamic jurisprudence is that no parent in their right mind would kill their own children; therefore, such acts of murder could never be fully intentional. While parents who kill their children cannot themselves be killed, they can very well be punished (Eshaqi 2001, pp. 197-202). True to form, Brian seems to have simply seized on the first clause of Article 202 that exempted him from qesās and omitted the punishment that was provided for in law. Brian did, however, get one thing right. Mothers who committed filicide were not given the same automatic exemption from qes $\bar{a} s$ as fathers. They were liable for it, and, unless they had a sympathetic judge who could be convinced of a mitigating factor by an attorney, a mother who committed filicide (including infanticide) could be executed at the demand of the father's family. This is what indeed happened to one Sohayla Qadiri in 2009 after she was convicted of killing her five-day-old son (Parsā-ālipur 2009). Eshaqi's proposed reform was not just about sexual equality, but would also have had the effect of mitigating the disproportionate application of the death penalty to women compared to men who commit the same crimes. So, while Iranian-Islamic law assumed diminished capacity on the part of filicidal fathers and provided a (slim) chance to seek leniency for filicidal mothers, American law required diminished capacity to be decided case by case. The distance between the two legal worlds on the question of filicide was not as great as Brian represented it.

The clumsiness of Brian's impromptu attempt at legal hybridization notwithstanding, pre-modern Islamic jurisprudence in the Middle East (including in Iran) was a hybrid of regulations that flowed from religious precepts (though interpretations of the Koran and teachings of the Prophet Muhammad) and pragmatic concessions to matters of governance (notably in taxation) and custom. In the modern period, Western legal codes and procedures were adapted into Middle Eastern legal practice, either through indigenous reform or colonial imposition. Those Western layers and strands remained durable even in the face of recent Islamist rejection (Osanloo 2006a, 2006b; Bedir 2004; Spannus 2013; Kia 1994; Hoffman 2010). The process of legal reform in Muslim-majority states generally reached personal status and family law later than other areas of law.

In Iran, the process of legal reform relating to family law intensified during the authoritarian reforms of the Pahlavi Dynasty (1925-1979) and reached an important milestone while Brian was still living in Iran. Even "progressive" legislation like the Marriage Law of 1931 (Amin 2002, pp. 114-41) or the Family Protection Law of 1967-enacted two years before Brian left Iran—sought to regulate rather than abrogate the religious underpinnings of male privilege in family law. It has been observed that women's quest for equality in Iran, as in Europe and elsewhere, has been entwined with (and often undermined by) maternalism across the political and ideological spectrum (Kashani-Sabet 2011). When the Islamic Republic overturned the FPL in February 1979, it was soon compelled to use European models of procedure to implement the "restoration" of Twelver Shi ite legal norms in matters of marriage and divorce, often with the same regulatory effect as the FPL. Ironically, Brian's dogged 
insistence on personally arguing for his rights in so many court appearances in the United States was similar-in style, not at all in substance - to the courtroom behavior of women in family court in Iran observed by Arzoo Osanloo and might also be considered a form of "rights talk (Osanloo 2006b, p. 200)," albeit a version informed by a striking degree of narcissism and an almost pathologically patriarchal mindset. The husbands of women seeking a khol' (as distinct from male-initiated talāq) divorce in Iran would have come into an Iranian family court with expectations of some sort of financial consideration (usually giving back the required mehriye or "bridal gift") before consenting to a divorce. It is this often tortuous process that takes up the time of family courts in Iran (Mir-Hosseini and Longinatto 2003). And that is for the dissolution of a regular marriage (nekāh), not the variety of marriage possible in Shi ism, and legal in Iran, that allows for time-specific contract marriages (Haeri 2014). The rejection of Brian's imaginary effort to remove himself from an American legal jurisdiction to Iran was, of course, rejected in 2002 and 2006. But it did not entirely settle the question of Iran being Brian's true "cultural home" that validated (in Brian's mind) his hyper-patriarchal efforts to control Mellie and Susan.

A crucial episode in the prosecution's theory of the crime was the confrontation between Mellie and Brian in the Learning Works Store on 17 August 2001, a week before Susan's murder. It was the focus of Miele's cross-examination of Mellie on the second day of the trial. It revealed how use of language marked a mobile, permeable cultural boundary between Iran and America. Judge Anderson also participated in the exchange, to seek clarification:

Judge Anderson: Why was [Brian] angry?

Amaneh: Oh, I told him, "Why you here? Because we just said goodbye." We left the McDonald [sic] and came to the [shopping] center. And I asked him, "Why are you here? Why are you following us?" And he said, speaking Farsi, "Shut up and speak Farsi [Persian]," and I said, "I am asking why you here? [Sic] Is that a big question?" He said, "Speak Farsi. [Or] shut up ... "

Miele: And then he got mad at you because you were questioning him for being around his daughter [emphasis added]?

Amaneh: He was mad at me because he was speaking Farsi and I did not want to speak Farsi because he was saying something that was not okay to say, you know, I didn't want to hear.

Miele: The only reason he's mad at you is because you won't speak Farsi with him?

Amaneh: Because he was telling me bad words and he didn't want me to speak English so people wouldn't hear [the Persian threats] because the way he talks so friendly like [in English], but if you know the divorce, you know what's going on.

Miele: I still don't understand why he's mad at you.

Amaneh: Because I asked him, "Why are you followed [sic] me?" Then I spoke English and he did not want me to speak English [emphases added] ...

Miele: As a result of this fight, argument, and the fact that Mr. Yasipour allegedly threatened to cut you up, were you afraid for Susan at that time?

Amaneh: No.

Miele: Why? 
Amaneh: Because at the time I thought he-

Mr. Dinges: Objection to the relevance, Your Honor. We are offering it to show anger at [Amaneh].

Mr. Miele: Their theory is that the child's in danger because [Brian] is angry at [Amaneh]. She is there. She can give her opinion as to why she wasn't fearful for Susan at the time. How is that not relevant?

Anderson: [Ma'am] Mr. Miele's question was, did you have any fear for your daughter at that time? You answer was no. And he's asked you the question then, why not? Are you able to express that?

Amaneh: Well, he said he would kill me. He didn't say he would kill Susan.

Miele: You were aware, were you not, on that particular day that Mr. Yasipour had had a history of mental problems, weren't you?

Amaneh: Kind of ... I knew he was difficult. I knew we have gone to many counselors. He had gone to many counselors, but I am not a psychologist so ...

Judge Anderson: Okay. (TY 2006, 7 March, pp. 69-75)

Brian deployed Persian to try and isolate Amaneh and Susan in the Learning Works and transport them all to an Iranian cultural context in full view of the American one. Amaneh refused him, in Persian and in English, preserving a line of defense that Brian was clearly trying to breach: the limits of his visitation time with Susan. She was also trying to deprive Brian of his ability to "talk friendly like" in English and obscure from observers his naked hostility towards her. English gave Mellie a measure of mobility away from the "family-oriented" version of an "Iranian" family Brian was trying to maintain. After his divorce from Betty Keller, his sister and oldest sibling, Fakhri, encouraged him to remarry. She arranged the marriage between Brian and Amaneh in Iran in 1992. I asked what Amaneh's mehriye was. "500,000 tumān," he said, "It's like \$500, cheap." It was his first victory over Amaneh, and there was only the slightest hint of a satisfied smile on his face. When I asked if the college-educated Amaneh had a job when they were together, he quickly asserted, "No, no she was just a housewife."

In court in 2006, Amaneh was also defending herself against Miele's tactical (but, still cruel) insinuations that, perhaps, she bore some responsibility for what happened to Susan. Didn't she know Brian was unbalanced? Implicitly: Couldn't she appreciate the looming danger to Susan? At the end of the exchange, Amaneh took a swipe at the insanity defense by refusing to agree that she observed signs of mental illness in Brian that would, in any way, mitigate or excuse his abusive behavior. Miele did not explore Amaneh's divorce and remarriage. Brian's suspicions about Amaneh's fidelity-for a time he doubted that Susan was his child - would later be introduced as evidence of Brian's pathological paranoia. Brian's defense team had to push back against the notion that his patriarchal paranoia was "normal" in Iran. However, Brian's behavior and the even the supportive testimony of other members of Brian's family made that difficult.

Brian's "Iranian" gender ideology came under scrutiny again on 13 March, the third day of the trial. The prosecution's witnesses had all completed their initial testimony and the defense began to call its witnesses to the stand. Miele began with Brian's sons, Brian Junior and Timothy S. (who went by Sam). The struggle for the narrative here centered on whether Brian's heated and protracted struggle for custody of his sons with Betty Keller informed his motive in killing Susan or not. Did the years of acrimonious and failed efforts to establish his control over Brian Jr. and Sam in the 1980s make him murderously desperate to retain control over Susan in 2001? Dinges prodded Brian Junior and Sam to admit that Brian was essentially frustrated because American courts denied his patriarchal 
authority, which he would have been able to take granted in Iran. The testimony of the sons drove the press coverage the next day (Farr 2006c). After testifying to his sense of his father's increasing mental instability in the weeks before Susan's murder, Brian Jr. provided some ammunition for the prosecution under cross-examination:

Dinges: I mean, they [Brian and Betty] disagreed?

Brian Jr.: Yeah. I mean, he would get upset. We was living in housing projects, trailer parks, and he always felt as if he had a good job, he was making good money, and he could never understand why the courts would not let him have custody of us, being that he was trying to get us out of an unsafe environment, and it really-in the long-run he was right because we was just out of control.

Dinges: Exactly. He never-he was always upset because the courts weren't doing what he knew was right, correct?

Brian Jr.: No. What he didn't understand, that's the way it is in America. He's from a different country. I understood that and I'd try to help him, but he just didn't understand that.

Dinges: He's from Iran and pretty much what the father says goes?

Brian Jr.: Yeah, much so, yeah. It's a totally different culture [emphasis added] ...

Dinges: And that's probably the same thing he was going through with Susan, frustration?

Brian Jr.: It's just something that—it was about to be the same thing all over again ... . (TY 2006, 13 March, pp. 151-53)

In trying to represent the complexity of the situation-cultural differences, an acrimonious divorce, a sense that his mother's home may not have the best place to grow up after all, the fact of his father's obsessive nature-Brian Jr. handed Dinges something he had been looking for: that Brian's murderous rage was fueled by a "totally different" Iranian cultural norm. Even if what Brian did was unacceptable in Iran, how he felt would have "made sense" in Iran. If Brian was essentially Iranian, then his motive was informed more by an alien cultural logic than mental instability. Even under cross-examination, Brian Jr. pushed back, "I know what you are trying to insinuate. But, come on, I have to live with this from my own soul ... I really think my father meant to hurt himself that day ... I think he was on the verge of killing himself (TY 2006, 14 March, pp. 153)." The challenge for the defense was not to simply "assimilate" him as an American with mental problems, but to portray him sympathetically as an Iranian immigrant whose mental problems were ultimately rooted in Iranian origins.

\section{2. "If He Is Not a White Christian, What Is He?": Mobility, Ethnicity, and Religion}

The next day, 14 March, the defense sought to bolster its case that Brian's behavior had been erratic for some time prior to Susan's murder and that, nonetheless, Susan and Brian's relationship had been normal and loving before 24 August. It was also on this day that there was a debate regarding whether or not to admit into evidence my "cultural expertise" in the form of a report with the cringe-inducing title of "The Perso-Islamic Context for the Actions of Brian Yasipour." In that report I pointed out the religious and legal norms against female infanticide. I noted that Brian's claim that his rape was ignored in the 1960s was plausible not least because state initiatives to prevent child abuse do not seem to have gotten underway in Iran until the 1990s. I also noted that Brian's conversion to Christianity in Iran just before immigration would have been unusual as well as problematic given his origins in a conservative South Tehran merchant family. The details of my report were not discussed in the 
press or in open court. Judge Anderson, Dinges, Miele, and Spring debated the admissibility of my report in chambers. Miele argued that my report would "certainly counter any argument that the Commonwealth is alluding [to] and actually brought up specifically in cross examination yesterday about [Brian] being Iranian the way [Iranians] controlled their situations and families." Dinges argued my report was irrelevant because the accuracy of Brian's perspective on Iranian culture was not as important as his state of mind at the time of the crime. The debate developed from there:

Judge Anderson: [You're] going to attempt to show me was the state of mind by Mr. Yasipour at the time of this killing, that he could not distinguish between right and wrong [i.e., the McNaughton standard for legal insanity]?

Mr. Miele: We're going to show you a state of mind that complies with McNaughton on all the requirements of McNaughton and that being certainly one aspect, one component of it. What we're trying to do is buttress, if you will, [the defense's psychiatric expert] Dr. [Pogos] Voskanian's opinions based on some cultural considerations. He is not a white Christian, as the Court once referred to him. He is not. He is Iranian. That's where he was born, raised, [and] lived his formative years. He was raised in the Muslim religion. That is what his core is. Whether he's changed to Christianity, whatever, that doesn't change what happened to him as a child when he was 12 or so and where- how he had to deal with it as a child and the environment that he lived in.

Judge Anderson pressed, "If he is not a white Christian, what is he?" Miele reached further into the logic of his cultural defense. "This is about culture, not the color of his skin. We're talking cultural differences." Judge Anderson reminded him of the pre-history of the trial, when they all thought it would be a jury trial. At that time Miele's concern was Brian would not get fair trial because the jury would be "white Christians ... They would be seeing [an] Iranian, who I said was a citizen and appears to be white and who I believe is Christian ... Now, you are taking me to task saying the Court has this preconceived notion [emphasis added] ... " The discussion became at once personal and theoretical:

Mr. Miele: You just-you do have a preconceived notion. You just acknowledged if only based upon his appearance and he's neither ... I didn't want him to be portrayed as a white Christian. I knew before then-before trial started, we'd discussed it on the defense that the Commonwealth at some point if we didn't they would certainly mention the fact that he is Iranian, and that's already happened, not through us, but through the Commonwealth's case.

Judge Anderson: ... [Your] concern was that the jury would see him as something else, and that's why the whole issue came up.

Miele: You're right, Judge.

Judge Anderson: I don't care if he is Iranian frankly.

Mr. Miele: I know you don't care. I understand that you don't care. I'm not accusing you of caring. I'm just saying you have to understand that because he is Iranian he comes from a different culture. They have different values. They have different ways of looking at things than you and I do, having been born and raised here in the US, and those things impact on him and how he deals with things, and Doctor—or Mr. [Anonymous'], I apologize, testimony will address that in part, particularly as it relates to how do you deal with being the victim of sexual abuse as a child in a Muslim country? How do you deal with that? What support is there available to you? I don't understand for the life of me how that isn't relevant. (TY 2006, 14 March, pp. 81-86) 
By insisting on the relevance of Iranian culture, but to a different end than Dinges, Miele and Spring were deploying a cultural defense to persuade the court to a more sympathetic version of Brian as a "whole client (Goel 2004)." Dinges again protested that the cultural testimony was not relevant because what mattered was Brian's motive as established by the record of his conduct, not conjecture about cultural influences from Iran that may or may not have been on his mind when he acted. Judge Anderson had already begun to turn — not on the question of whether the McNaughton standard had been met, but on whether the cultural defense was relevant to the insanity defense. Anderson ruled that "I will try and understand the connection you are making, Mr. Miele," and that my report would be admitted into evidence as advisory to the court. It is possible that all the men knew something had changed in the discussion. Not only was the insanity defense not going to be undermined by the "logic" of Iranian culture, but, to the contrary, it might be strengthened. Brian's rape in Iran might be seen as more traumatic (because he received no help there), and, therefore, more plausibly the psychic epicenter of Brian's PTSD. Dr. Voskanian opined that Brian's PTSD was somehow activated the morning after Brian lost his bid to gain more visitation rights and induced the "dissociative state" in which he killed Susan later that afternoon. In this rendering, Brian's trauma in Iran was the real root of the tragedy in Williamsport. If accepted as true, this might admit some glimmer of Brian's humanity into the dark horror of his act.

The Yasipour family's humanity was portrayed in the earliest press reports on the trial—even Brian's humanity. "Brian A. Yasipour Sr. clenched his eyes but no tears would come as photographs and video of his slain daughter-her pale lips slightly open, her stuffed animals and dolls surrounding her and bouquets of 'sweetheart' roses on her lifeless chest-were shown on Monday, the second day of his trial in Lycoming County court (Farr 2006a)." Farr's coverage of this closed with a humanizing depiction of Brian and his family:

For much of the day, Yasipour-a hirsute man who was dressed in a forest-green prison jumpsuit—stared blankly at the ground. His two sons, Brian Jr. and Timothy, sat behind him in support. The only time Yasipour expressed any emotion was when graphic pictures and videotape of his dead daughter's body were shown. (Farr 2006a)

Looking back on this episode in her life, Farr told me that she felt some compassion for Brian, despite the horror of what he did:

The brutality of it never left me-those autopsy slides. Seeing just such a small body so cut up was really, it was ... It was a shock. It was a realization that the world may be, you know, wasn't as kind a place as I had previously hoped. I also felt, like, I felt a tinge of-I don't know-sadness for Brian in a way because he was painted ... as a very lonely man. And I didn't understand why if he was so lonely that he would take the one thing out of this world that seemed to matter most. (Farr 2014)

The room for mercy for filicidal parents—-seen both in Iranian and American law-is rooted in an assumption that before there was a murderous mother or father, there was a "normal" mother or father and that some unusual circumstance or disease must have changed the equation. There is evidence of this in Pennsylvania's colonial history-underscoring the fact that legal and cultural norms are not static in any context: it was not until after 1785, when the penalty in Pennsylvania for maternal infanticide provided for imprisonment rather than execution, that the conviction rate increased from $26 \%$ to $42.8 \%$, (Rowe 1991). For a similar sense of mercy to be activated for Brian in the 21st century, it was essential for Miele and Spring to make credible the idea Brian was in a dissociative state at the time of the crime. It had to be a state of mind resulting from PTSD rooted in the trauma of childhood rape back in Iran. That had to become a more plausible scenario than Brian acting vindictively, even impulsively, after a bad day in court. This aspect of the argument was discussed in open court during the dueling testimony of psychological experts. 
Decisive for Anderson, in the end, was the psychological testimony, not of the expert witnesses for the prosecution or defense, but of one of the psychologists who had evaluated Brian in 1995, Dr. Jacqueline Sallade. She had written this:

Mr. Yasipour is preoccupied with depressive obsessions such as the feelings of worthlessness, hopelessness, frustration, [of being] mistaken, blameworthy and pessimistic, as tearful, suicidal, and at times homicidal. He has thoughts when he is rejected of hurting people, burning their houses down, killing them, etc., but he has never hurt anyone.

Judge Anderson applied the implications of this assessment for the events of 24 August 2001:

Picture Mr. Yasipour this day. Marriage gone. Job gone. Wife is against him. Attorney Mr. Felix fired the night before because he would not agree with him. Mr. Yasipour felt that he [Felix] turned on him for a decision that he'd [Yasipour] made. Mr. Yasipour went through a litany of witnesses that showed a pathetic effort to get people to come to his custody hearing. He went to neighbors. He went to people he thought were friends. He went to Molito's Sub Shop where he bought subs to try to get the people that worked at the sub shop to come down and testify for him. He was rejected. He went to his sons. They would not come up. He was running on a bad batch of road. The next day he gets there [i.e., the custody hearing]. What happens? Man, not only is he rejected, he's dressed down in severe style, and then he leaves. What's he got left? He's got Susan. He's got Susan.... First Susan says, "I don't want to go with you." [Brian asks Amaneh], "Will you help?" She goes with him. Now they get into the quiet of the home. What's she [i.e., Susan] want to do? Calls Mom. A form of rejection. It's the ultimate and the final rejection. And I believe that Dr. Sallade, who opined this six years before the fact, had it right on. (TY 2006, p. 15, 24 March; Sallade's testimony was on 15 March, per (TY 2006, pp. 143-44, 15 March))

Anderson rejected the "cultural defense" to the extent that it supported Voskanian's diagnosis of PTSD from a trauma experienced in Iran. He also rejected the "cultural prosecution" advanced by Dinges that Iranian norms informed and reinforced Brian's ability to form the intent to murder Susan. In convicting Brian of murder in the third degree, Anderson was accepting that Brian's ability to form intent consistent with murder in the first degree was compromised by his mental condition. In a sense, he wound up in the same place Brian would have started from under Iranian law: diminished capacity that reduced but did not eliminate criminal responsibility. Stephanie Farr covered the verdict with the headline, "Guilty but Mentally Ill: Judge Develops His Own Theory of Why Yasipour Slew His Daughter" (Farr 2006d)."

What was pointedly missing in Anderson's verdict, and much of the reaction to it, was any reference to Iran. The cultural defense had neutralized the cultural prosecution to the extent that the whole debate was absent in the verdict. From the standpoint of the Williamsport community at this point, Brian was assimilated into the American context physically and conceptually; it also immobilized him as a convicted murderer. A report of the verdict posted on WNEP's website at 4:57 p.m. made no mention of the family's immigrant background though it referred to Mellie by her Iranian name, Amaneh (WNEP 2006). Of course, it is not as though everyone suddenly forgot the Yasipours' background. What it is important here that the Yasipours' background could be framed differently at different times. It could be framed differently for Brian than for his victims. In 2014, news of Brian's death in the Williamsport Sun-Gazette referred to him as an "Iranian immigrant living in Williamsport when he stabbed his daughter in August 2001, saying he feared his wife planned to take the girl back to their native country (Williamsport Sun-Gazette 2014, Man Jailed for Murder Dead at 64)." Susan was born in the United States; she died in her native country. In the immediate wake of the verdict in 2006, the family was "native" to Williamsport. Brian, who never forgave Judge Anderson for not finding him innocent by reason of insanity and who had sought Anderson's recusal because of their history, may have benefitted from Anderson's ability to see his humanity, to see him as a 
person who had somehow changed and became incapable of restraining a murderous impulse. Even though he knew of Brian's difficult history, Judge Anderson had been as surprised as everyone else at Brian's violent turn. "No, to answer your question," he later told me, "I did not see this coming (Anderson 2010)."

Anderson also felt that Brian was not capable of true remorse, and this was reflected in his response to Brian's post-sentence motion (Anderson 2006, p. 2). It was a view I came to share after interviewing Brian and reflecting on something that was not presented at trial: Brian's confession. Anderson had ruled the confession inadmissible because Brian had not been properly Mirandized-a very American legal rationale. The content of the confession-the way Brian articulated his filicidal delusion-reminds us that immobilizing Brian physically and even in a specific discursive context does not exhaust the imaginary possibilities of im/mobility.

\section{3. "I Am a Good Father": Imaginary Im/Mobility in Brian's Confession and Internet Debates about Brian's Religion}

Outside the court and on the Internet was another forum in which the trial was being discussed. The Forums For Justice discussions of Brian's insanity defense and ethnicity, although they were happening in real time and involved some people who attended the trial and knew some of the participants, were not being monitored by the press. It was the other way around, actually, with FFJ posters updating the group with copies of press coverage (usually authored by Stephanie Farr for the Williamsport Sun-Gazette) and commenting on both the coverage and reports from the members who attended the trial.

As noted earlier, I became aware of FFJ when I was looking to follow events from afar at the time of trial. It was immediately apparent that the sympathies of the FFJ posters were with the prosecution and Mellie. These sympathies were refracted through an Islamophobic (and homophobic) ideological prism. Their compassion for Mellie (and even Brian's other family members) animated the FFJ postings almost as much as their wrath for Brian. The most frequent posters-often in direct dialog-were "LurkerXIV" and "Quinn." Quinn was a local woman who was able to attend the trial, often serving as the reporter for the group.

LurkerXIV (15 March, 5:06 p.m.): The sooner this freak Yasipour is put behind bars for life, the better. I hope Mellie is holding up OK. This must be agonizing for her.

Quinn (16 March, 10:49 p.m.): Mellie is an amazing women [sic]. She has a strength and understanding that I would never have. Brian has two older sons whom I have met and like, today we had lunch together. They are in an awful position as well; they love their father and don't deny that this happened but are strong in thier [sic] belief that he was not in his right mind at the time because of a (questionable IMO) history of mental problems and have forgiven Brian. Mellie and the boys have a wonderful relationship even tho they have different opinions about the case.

Quinn did not confine herself to observing the trial and engaging with the Yasipours. As the defense's theory of the crime played out it court, she desperately looked for ways to pushback and actually bolster the prosecution's case:

LurkerXIV (17 March, 4:05 p.m.): Thank you [Quinn] for actually being there at the Court House for her during the trial.

Reading the news reports makes me really detest some psychiatrists. The ones the defense has hired will say anything for the money. They are just hired hands. As for Yasipour being molested while he was a boy in Iran...that culture (Muslim) accepts and encourages male homosexuality, so I don't know why it would upset him so much. 
Quinn (17 March, 4:30 p.m.): The defence [sic] is saying that that is not accepted or acknowledged in Iran. They conceed [sic] that one man would never do that to another. There is no help for those that confess to a man on man rape. Miele is saying that is why he came to America, changed his name from Huessain (SP) to Brian, changed religion and the beliefs and way of living. They are supposed to have a culture expert coming in to testify $\cdots$

LurkerXIV (19 March, 11:20 p.m.): I wonder who their "culture expert" is and what he/she will say. Homosexuality in the Islamic world is a very convoluted business. Culturally, it is most certainly a common practice in Iraq and Iran; whether it is punished or not depends on who is in power.

Here is a good article that explains why:

http:/ / www.frontpagemag.com/articles...le.asp?ID=5704

Quinn (21 March, 12:03 a.m.): Thank you for the article. Any suggestions how I could get in the hands of the D.A. Dinges? I would like him to see this. I will be in court tomorrow. If it helps I do know the invesigater [sic] Steve Sorage.

The link to the article on FrontPageMagazine, whose motto currently is, "Inside Every Liberal is a Totalitarian Screaming to Get Out," results in a "not found, error 404." However, a quick search for "homosexuality" on the site yields dozens of articles lamenting both the prevalence of homosexual rape and intolerance towards the LGBTQ communities in majority Muslim Middle Eastern countries. It is an odd mix of Islamophobic orientalism and homophobia that animates many of the headlines on this site. The article that most seemed to resonate with LurkerXIV's description was an excerpt from Serge Trifkovic's The Sword of the Prophet: A Politically-Incorrect Guide to Islam adapted by Robert Locke on 23 January 2003 and entitled, "Islam's Love-Hate Relationship with Homosexuality (Locke 2003)."

Brian's sexuality was part of the courtroom debate about his state of mind at the moment of the crime. The prosecution's evidence of his sexual deviancy took two forms: testimony about him leering at a young (female) swimming instructor during one of Susan's lessons and a selection of pornographic video tapes that he tried to dispose of the day of the murder that featured transgender sex workers. For the defense, these same videos were presented as evidence of Brian's lingering trauma from being raped by an older boy back in Iran (the prosecution never stipulated the fact of Brian's rape, much less its effects). However, LurkerXIV and Quinn's "research" on Islam and homosexuality was part of a cultural framing of Brian that was at once Islamophobic (in that it embraced the idea that Brian's Muslim background defined him more than any other attribute and framed that Muslim background as inherently inimical to America/Christianity) and homophobic (in conflating rape with consensual sex). Quinn seems to have assumed that these biases were somehow a fact that their government should embrace and act upon. Quinn and Lurker XIVs' reaction to Anderson's verdict, then, was hardly surprising. The verdict prompted posts from a few others who had not commented on the trial while it was in progress, including, as we shall see, from Mellie Yasipour. Lurker XIV fumed, "I'm going to keep an eye on Anderson, and if he does a repeat performance of going easy on a child abuser or child-murderer, I'm going to get Bill O'Reilly on his case! (FFJ 2006, March 24, 7:04 p.m.)."

The importance of these Internet posts is that they reflect precisely the attitudes that Miele and Spring worried would influence a jury pool in their part of Pennsylvania. The combination of the transcript of sidebar in Judge Anderson's chambers and the Forum for Justice posts serve as proxies for the local mindset and how it might have impacted understanding of the Yasipour family, Brian in particular. As perhaps a further indication of the accuracy of Miele's characterization of Lycoming County Pennsylvania, Trump carried the county $70.46 \%$ to $25.75 \%$ in the 2016 Presidential election (http:/ / www.electionreturns.pa.gov), the best margin of victory for a Republican presidential candidate recorded there this century. 
The temptation here, perhaps, is to assume that this vitriolic and essentially Orientalist "othering" of Brian by the FFJ was simply a local manifestation of a prevailing hegemonic discourse. Mohsen Mobasher has analyzed the effect of a changing national discourse about Iran on Iranian-Americans in Texas. Many that he interviewed in his study reported a sense of alienation from the rest of American society-despite enjoying other measures of professional and economic success in America-because of the negative image of Iran in American culture stemming from the Iranian Revolution of 1977-1979 and Hostage Crisis of 1979-1981 and reawakened with Iran's inclusion in the "Axis of Evil" in the aftermath of 9/11 (Mobasher 2012, pp. 7-8, 53-60,64-66). Brian killed Susan in a different America than the one he was tried in. On 24 August 2001, President George W. Bush was going to be in Williamsport for the Little League Baseball Championships. Most police resources that night were deployed to provide security for the Little Leaguers and the President. Because it was a bench trial, the defense team did not have not to contend with an anti-Iranian jury pool whose animosity would factor in the horrors that would unfold just 18 days after the murder.

It is worth noting that the Williamsport-based posters to the FFJ were not just supportive of Mellie in their posts. They distinguished between Brian Sr. and the rest of his family and expressed empathy for them throughout their posts even as they expressed outrage at Anderson's verdict. But the FFJ posters did not hear everything at the trial. For an obvious reason-the Fifth Amendment-they did not hear from Brian at trial. They also did not hear about Brian's confession during the trial. This revised narrative can include both.

Brian did not feel defined by his crime or by his national or religious identity, as far as I can tell. Certainly, as we have seen, he did not seem conflicted about his mobility between Iranian-Muslim and American-Christian contexts, nor was he particularly articulate about either religious doctrine. And, as I spoke to him in June 2010, his hyper-patriarchal gender ideology seemed more idiosyncratic-even as he discussed it in terms of mobility between "Iranian" and "American" contexts.

"What should people know about you?" I asked.

"That I am a good father."

I paused [I could scarcely believe what I was hearing]. "Why do you think you are a good father?" I asked.

"Because I care."

"Anything else? Anything you did to be a good father?"

No answer.

"Why do you think others might not think you are a good father?"

"Because of divorce."

I asked him what he remembered about Susan's death. He said he remembered stabbing her, but not why. This surprised me. All previous statements attributed to him indicated that he did not remember the act of killing Susan. I asked if he remembered why he had cleaned Susan up after he killed her. At trial, the debate was whether he was trying to cover up his crime or was engaging in some sort of confused mourning ritual (Farr 2006b). He said, "I did not want them to know which knife I had used, so I washed them."

I said, "You were trying to convince the police that you did not kill Susan?"

"Yes."

"Did you plan to flee at some point, to escape?"

"No."

"So you thought you might convince everyone you had not harmed Susan and just continue living in Williamsport."

"Yes." 
I asked why, in his view, Amaneh wanted to leave the marriage. Could he see her side at all? I wondered to myself. "Because I was too obsessive."

I asked if anything happened that made it more likely that Susan would die. He mentioned that the custody hearing that morning had gone badly. He was only going to have Susan for three hours, three days a week, not eight. But, I reminded him, those five hours were going to be school. It is not as though Amaneh would actually have Susan with her more of the time.

"I wanted to get weekend visitation in exchange."

Even so, how did this inform his filicidal thoughts? I asked him, "Were you afraid that Amaneh would take Susan to Iran?"

"Yes."

I asked him what would be so bad about Amaneh living in Iran with Susan.

"It would not be nice to have a woman alone with her child."

"Well, couldn't you just go to Iran yourself and win your rights more easily?" I asked.

"I did not want to live in Iran," he offered. The reductive implication of what he was saying was that he killed his daughter so he would not have to live in Iran. This was at odds with the prosecution's theory that he planned to flee to Iran, but also with Brian's own attempts to be judged by Iranian legal standards in America. Could a man kill his daughter just to preserve the power of his own mobility? A member of Brian's former church in Montoursville, a witness for the prosecution, had said, "Brian Yasipour is the focus of Brian Yasipour's life (YT, 13 March, p. 20)." But, even with that, there were so many other options than murder. Filicidal ideation often includes a notion that killing the child is necessary to avoid a worse fate. I did not get the sense that he believed that when I spoke to him. What about the day of the crime?

It was not until I reviewed Brian's suppressed confession that I felt I understood the tortured logic of his filicidal delusion-the fate worse than death that would "inevitably" result from Susan growing up without him in Iran. Judge Anderson ruled on a pre-trial motion to suppress Brian's confession on the night of the murder on 22 November 2002 (Anderson 2002). The text of Anderson's order preserved the remarkable substance of Brian's confession itself. In his confession Brian drew a direct causal line between Judge Butt's decision to reduce his visitation and "the fact his child would be forced into prostitution (Anderson 2002, p. 4)." Why would this happen? Because, somehow, Amaneh might take Susan to Iran. Somehow the loss of his visitation rights, the loss of his control over Susan made this fear more concrete to him. But, he allegedly added, "she [Susan] did not have to worry about it anymore and she was better off now (Ibid.)." Anderson did not find police to be lying about Brian's statements, just that the confession was inadmissible because Brian had not been Mirandized. In these alleged statements, we see the scope of Brian's fears about losing control of Susan's mobility. In his mind at the time, the loss of control would lead to her sexual violation, if not through an assault (as had been his own experience) than through circumstances reducing her to sexual slavery. Even though Susan was much too young to be held to cruel account by a deranged father for sexual impropriety in a classic honor killing case, he could imagine an "inescapable" future when she would be old enough to "dishonor" him in Iran and destroy his wish to be a "good father." Nevertheless, despite his protestations in court about Iran being "family oriented," despite his attempts to import a more "Iranian" marriage into the United States, and despite his efforts to avoid imprisonment and responsibility for his crime, Brian wanted to stay in America. In the immediate wake of Susan's murder, it appears that Brian decided to risk being an American convict rather than being a repatriated Iranian fugitive from American law.

\section{Concluding Discussion: "Regimes of Im/Mobility" and Historical Analysis}

One of the limitations of this study, besides the obvious limitations of any case study, is that its methodology evolved from a non-research context and without a premeditated research design to explore the explanatory power of the many theoretical paradigms that might be reasonably applied. For example, it is unlikely that if I had begun with the intention of exploring regimes-of-im/mobility (or any 
other theoretical paradigm) in a given court system that I would have begun with a particular case. Rather, I would have established a long-term research project that relied on established relationships with a particular court that facilitated courtroom observations, routinized the review of court records and established protocols for interviewing participants in trials. I would have more deliberately integrated field research methodology with historical methodology to see what specific lines of inquiry emerged. Thinking about the most important sources for this study - the trial transcript and interviews-I can well imagine them, as part of a future study, being read comparatively with similar sources or even with literary/poetic sources for resonant themes and issues. That would have been far beyond the scope of this article, but there is extensive academic literature on the literary and memoir output of Iranian-Americans to take as a point of departure for such a future study (See, as examples, (Elahi 2006; Malek 2006; Karim and Rahimieh 2008); the last reference is an introduction to several studies in a themed issue of MELUS).

Nonetheless, the use of a "regimes of im/mobility" in a more retrospective way in this case has been helpful. And I would not claim to have exhausted its potential here. I applied it to a multi-focal analysis of gender and ethnicity and religion because those factors seemed linked at several points in the narrative of trial and were expressed in terms that resonated with the im/mobility framework. We are increasingly called upon to assess the intersection of multiple factors in social and historical analyses. The regimes of mobility approach can help us with this challenge. It can help us see and describe all "moving parts" in an unfolding event or process-even in the face of a considerable detail as in a microhistorical case study. It can do this because im/mobility-like gender-is such an elemental part of the human experience. Its expression is likely to be observable in a variety of sources, and, it will be part of any process we might choose to examine. To paraphrase Joan Wallach Scott, im/mobility is a "useful category of historical analysis (Scott 1999)." Furthermore, rather than compete with other lines of inquiry, it can add visibility to them.

It would, of course, be wrong to suggest that Brian was a typical Iranian, American, or Iranian-American, or, that the tragic experiences of the Yasipour family were a representative microcosm of the Iranian-American experience. But the very uniqueness of their circumstances generated an extensive record from a variety of vantage points. This allows us to appreciate the relationship between the specific (personal and local) to wider frames of analysis. In any microhistory, the challenge is to see the forest though a careful examination of a tree. In this case, however, we have two "forests" - Iranian and American. We found certain aspects of these "forests"-gender, religion, ethnicity-were important to examine together through a complicated set of circumstances using the prism of im/mobility. In Brian, though, we had a very strange "tree" in the foreground of the analysis. I will conclude by briefly reviewing how the "regimes of im/mobility" approach can draw the analytical eye not just toward the wider context but enrich our understanding of the particular. Brian was not the only tree in the forest.

Though I only met with lead investigating officer Stephen Sorage once, on 10 June 2010, I think of him as the man who came to know Brian best. He coined a most apt term to describe Brian's default state of mind: "Brianland". In Brianland, one did not have to answer for any harmful action to others or stick with any idea or commitment that conflicted with one's narrow interest. When I presented my preliminary research about this case at the Iranian Studies Conference in 2014, Ali Akbar Mahdi commented that Brian's agency was most visible in apparent moments of cultural vacuum, when it seemed to others (e.g., officers of the court, members of the community) that none of the imaginable identities-Iranian, American, Iranian-American, Muslim, Christian, White-applied to Brian. Rather than simply embracing or accepting a liminal status, Brian seemed to actively project a social identity that suited his immediate circumstances best. This suggests that Brian's erratic agency was not about embracing a "core identity," but about the freedom to move among different social identities in Iran and America. Brian's idiosyncratic picking and choosing of American and Iranian cultural values (or his readings of them) - his imaginary "hypermobility" in Brianland-bewildered observers in Williamsport because of the cultural plausibility of each of the identities he projected into 
the "vacuum." Furthermore, the cultures that he navigated between were not static and representations of them were not settled. Though the images of Iran constructed by the prosecution and defense were essentially negative, they were not identical. Judge Anderson came to accept that Brian's frightening version of "family-oriented" Iran was not accurate.

In reflecting on this study as a microhistory in the introduction, we noted the differences between Brian's situation and that of Ginzburg's Menocchio. There is also a similarity. In both cases, the legal culpability of the accused rested on the question of their sanity. Assessments of their sanity rested, in part, on how "alien" these individuals were: there was an imaginary banishment to another cultural place. Among the books used to establish Menocchio's deliberate indulgence of heretical doctrines was an Italian adaptation of the Koran (Ginzburg et al. 1993, p. 43). By contrast, the courtroom debates about Brian's ethnicity and sanity led to a nullification of those issues, letting the reality of his mental illness become a mitigating factor in his crime. Factoring in im/mobility into the microhistorical analysis of Brian's trial facilitates our ability to follow Brian's imaginary mobility between Iran and America. It also helps us notice the shifts in his social identity over time as perceived by others. As bewildering as Brian's imaginary hypermobility seemed to others during the time of his trial, it was built on a history of actual, physical mobility. At the same time, imaginary mobility seems to be at work in shifting community perceptions of the Yasipour family: sometimes they were Williamsport natives (Americans) and sometimes they were Iranian immigrants. Thinking of the relationship between imaginary and actual mobility helps the qualitative researcher reflect on these conceptual shifts as integral to an historical process rather than as disruptions. This is no less true in a microhistorical analysis with many details to consider. Consider a detail that illustrates the material consequences of imaginary im/mobility; they did not just apply to Brian, but to the court itself. In 2005, Miele and Spring sought a continuance to find and depose Brian's brother about Brian's medical history and in anticipation of the need for family testimony regarding mitigating factors in the (death) penalty phase of the trial. Anderson denied the continuance with this explanation:

The difficulty lies in obtaining the brother's testimony. No one has spoken to [the] defendant's brother, no one has an address, and therefore the content of his testimony is at this time uncertain. If alive, [the] defendant's brother is in Iran, a country [with] which the United States has limited diplomatic relations. Counsel concedes they cannot travel to Iran and it is highly unlikely that defendant's brother would be able to travel to the United States. Counsel's plan, if the continuance is granted, is to find [the] defendant's brother through a law office in Chicago. This law office maintains contacts in Iran. If found, defense counsel feels that arrangements can be made through the Pakistani Embassy to obtain a Visa for [the] defendant's brother to travel to Dubai in the United Arab Emirates. Counsel would then either arrange for some type of video conferencing or, as a last resort, proceed to Dubai to take his deposition for trial. The Court is keenly aware, and is sensitive to the fact this is a death penalty case and, accordingly, wishes to proceed in a manner that is cautious and accommodating to the defense. But, while the Court applauds defense counsel for leaving no stone unturned, the logistics of this particular situation are far beyond speculative. There is no assurance that anything can be accomplished by this intricate and costly procedure [emphasis added]; no one can represent to the Court what the testimony of [the] defendant's brother will be, or even that he can be found. Accordingly, the motion for continuance must be denied. (Anderson 2005, p. 2; emphasis added.)

However much the defense might want to emphasize the role of Brian's Iranian origins, there were practical limits to that. This small example may not be what first comes to mind as a governmental "regime of im/mobility" rationally regulating the movement of "people, goods, capital and certain forms of knowledge (Baker 2016, p. 152)," but it was certainly an instance of that phenomenon with direct consequences for Brian. The writ and resources of the Lycoming County Court system could not contend with multiple "regimes" that added time and cost to the process of preparing Brian's defense to the fullest possible extent. Furthermore, there was no getting away from the fact that Brian was a part 
of the Williamsport community - especially its court system. The trial focused on his hyper-patriarchal paranoia as a function of his Iranian origins. At the same time, Miele, Spring, and Anderson recalled that he was briefly active in a local men's rights group (though, unfortunately, I do not have a clear sense of what that involvement entailed). Spring had worked with Brian while she defended his sons against criminal charges. Miele vaguely remembered Brian striking up a conversation with him about father's rights when their paths crossed in the Lycoming County Court Building. In Williamsport, Brian was chafing not against a major regime of im/mobility rooted in U.S. immigration policy, but against the regulation of his power in "his" household: when and where he could see his child. From that vantage point, a "family-oriented" Iran that would accommodate his (by his own admission) obsessive personality might be a compelling mirage to run towards. Yes, Iranian law has more lenient defaults for filicidal fathers, as Brian opined, but not at all to the extent that he claimed. Also, Brian did not know about efforts like that of Eshaqi to change that. Egalitarian reformism, though unsuccessful so far, is also part of Iran's actual, diverse, living, and changing culture. In a qualitative analysis informed by considerations of im/mobility, the unbridgeable contrast between reductive conceptions of America and Iran falters in the face of observable similarities between Iranian and American responses to the horrors of filicide.

Even reductive constructions such as "Iranian" or "American" may not be consistently applied. The same FFJ posters that expressed such vitriolic orientalism in their judgment of Brian's actions also embraced Mellie and Susan as their own-and as being American Christians. They could have read Mellie, in particular, as a Muslim Iranian immigrant who was the victim of the patriarchal norms of her culture of origin-a version of "colonial feminism" that scholars like Leila Ahmed (Ahmed 1992) and Lila Abu-Lughod (Abu-Lughod 2013) have critiqued with reference to European and American foreign policy in the Middle East. Williamsport's embrace of Susan and Mellie does not seem to have been expressed that way. And Mellie seems to have felt that embrace. Other than court records, we have two other public records of Mellie's perspective at the time. The first was one of the last FFJ posts about the trial, "I am finding people across the country who acknowledge this brutal murder. I wish Susan (whose love toward every individual was under no condition [i.e., showed unconditional love to others]) was here to experience the love and compassion once more (FFJ 2006, 28 March, 8:35 a.m.)." Quinn reported visiting Susan's grave in the cemetery the previous day, leaving an "Easters gift" and meeting with Mellie afterward.

It was a member of Stephen Sorage's church who donated the plot for Susan's burial. Sorage, who broke down at the sight of her autopsy, kept a picture of her on at his desk. It kept him focused on seeking justice for Susan. In our one and only meeting, he showed the picture to me. In the picture, Susan was smiling and safe, as if nothing could ever happen to her. It reminded me of the picture on a website memorializing her among other victims of domestic violence in her American home of Williamsport, Pennsylvania (An Empty Place at the Table 2005). The site mentions a "history of domestic violence" in Mellie and Brian's relationship prior to the murder-the only assertion of that we have in the historical record. Mellie and Susan, again, are just Williamsport natives-no mention of Iran. As a child, of course, Susan's mobility was always constrained. The microhistorical examination of her father's crime gives us a window on her agency and mobility between Iran and America also. She had visited Iran with her parents and knew Persian. We know she defended her mother when Brian threatened Mellie in Persian in their confrontation in the Learning Works. We also know that she tried to reassure her father that Mellie was not going to take her to Iran. When her father was selfish and cruel, Susan was kind and brave. In remembrance of lost loved ones, Iranians often quote a couplet by the 14th-century poet Hafez, "One whose heart is born into love never dies; what remains of us is written upon the record of the world." Susan's place in that record is no less valuable for being all too brief. 


\section{A Note on Methodology}

In the end, I have to defer to readers to judge whether I have accounted for my own role sufficiently in the analysis because there is no way to write it out of the story. One unavoidable consequence of my role is that some participants would not talk to me after the fact, notably the prosecutors and Amaneh. My interviews with Judge Anderson (Anderson 2010), Stephanie Farr (Farr 2014), Nicole Spring, and William Miele (Miele and Spring 2010) were recorded, in keeping with my preferred approach to oral history. After an initial meeting on 10 June 2010, Agent Sorage would not respond to requests for a recorded interview. I was not permitted to bring recording equipment to interview Brian Yasipour in prison (Yasipour 2010). Therefore, my descriptions of those interviews rely on extensive notes that I wrote up within hours of those meetings. Transliterations of Persian words follow a modified version of the Library of Congress system, without diacritics except for the ayn and hamza. Vowels were rendered as follows: e/i, o/ $\mathrm{u}, \mathrm{a} / \bar{a}$.

Acknowledgments: This research was supported by a University of Michigan-Dearborn Office of Research and Sponsored Projects Campus Grant (2009-2010). There are many colleagues I would like to thank for their input and advice as I worked on this project and presented aspects of it at conferences over the years (or went and on about it over coffee!): Carolyn Kraus, Elaine Clark, Arzu Osanloo, Kathryn Babayan, Firoozeh Kashani-Sabet, Persis Karim, Amy Malek, Ali Akbar Mahdi, Kristin Poling, Arang Keshavarzian, Ali Mirsepassian, Sally Howell, Marty Hershock (my microhistory guru), and Georgina Hickey. I also wish to thank Lycoming County Court staff-in particular, Dawn Sweeley-for their assistance in securing transcripts of the trial. I also should note the help provided to me by student assistant in 2008-9, Maryam Abbas, as I began to gather information to work on this project. I also wish to thank Viola Thimm for generously introducing me to im/mobility as an analytical framework. I benefitted very much from the comments of the anonymous peer reviewers. My wife, Amelia Amin, always provides loving support, but I simply could not have completed the revisions to this article successfully this summer without her patient and insightful feedback. All remaining mistakes of interpretation or detail are mine.

Conflicts of Interest: As noted, I did participate pro bono as a "cultural expert" for the attorneys representing Brian Yasipour at trial. My decision to study this event came after the trial was concluded and all interviews occurred after the legal process was over. Furthermore, as Brian Yasipour is now deceased, there is no way my analysis can have any impact on his sentence. The funding sponsors had no role in the design of the study, in the collection or interpretation of data, in the writing of the manuscript, or in the decision to publish the results.

\section{Appendix A}

Table A1. Chronology.

\begin{tabular}{ll}
\hline 1950 & Hosayn Yasipour born to a South Tehran merchant family. \\
\hline ca. 1962 & Many years later, Brian reported that he was raped by an older boy around this time. \\
\hline 1968-1969 & $\begin{array}{l}\text { Brian (Hosayn) leaves Iran in 1968 (converts secretly to Christianity before leaving), } \\
\text { arrives in the United States in 1969, drops out of junior college, and begins a series of } \\
\text { sales jobs while marrying and starting a family in Williamsport, Pennsylvania. }\end{array}$ \\
\hline ca.1980-1990 & A decade of custody battles with first ex-wife, Betty Keller. \\
\hline 1992 & Brian and Amaneh (Mellie) Khatun marry in Iran as Muslims. \\
\hline 1994 & $\begin{array}{l}\text { Brian fired from his job at Monumental Life Insurance company; he begins a wrongful } \\
\text { termination lawsuit. }\end{array}$ \\
\hline 1995 & Psychologist Dr. Sallade assesses Brian for Social Security disability status. \\
\hline $1995-1996$ & $\begin{array}{l}\text { Brian treated for Social Security disability status. Susan Marie Yasipour born } \\
\text { 28 August 1996. }\end{array}$ \\
\hline January 1999 & Brian and Mellie separate; Mellie has primary custody. \\
\hline June-October 2000 & Brian restricted to supervised visitation after an attempt to kidnap Susan. \\
\hline May 2001 & Brian suffers stroke; his behavior becomes more erratic as custody litigation drags on. \\
\hline 24 August 2001 & Brian kills Susan and is arrested the same evening. \\
\hline
\end{tabular}


Table A1. Cont.

\begin{tabular}{ll}
\hline 2001-2002 & $\begin{array}{l}\text { Motion to suppress confession granted; Brian spends much of this time considered } \\
\text { unfit to stand trial. }\end{array}$ \\
\hline 10 December 2002 & $\begin{array}{l}\text { Brian unsuccessfully challenges the divorce in a hearing; his courtroom declaration, the } \\
\text { principal subject of this analysis, happens on this date. }\end{array}$ \\
\hline 22 February 2006 & District Attorney waives the death penalty in exchange for a bench trial. \\
\hline March 2006 & Trial and verdict (third degree murder, and tampering with evidence). \\
\hline June 2006 & Brian sentenced to 22 and a half years, with time served. \\
\hline August 2008 & BBrian's 2008 appeal rejected by Pennsylvanian Superior Court. \\
\hline 2 August 2014 & $\begin{array}{l}\text { Brian dies of natural causes in Laurel-Highlands prison facility, Pennsylvania. He had } \\
\text { suffered for years with untreated diabetes prior to his first stroke in 2001, and had } \\
\text { several strokes while in prison. }\end{array}$ \\
\hline
\end{tabular}

\section{References and Notes}

Abu-Lughod, Lila. 2013. Do Muslim Women Need Saving? Cambridge: Harvard University Press.

Ahmed, Leila. 1992. Women and Gender in Islam: Historical Roots of a Modern Debate. New Haven: Yale University Press.

Alba, Richard, and Victor Roe. 1997. Rethinking Assimilation Theory for a New Era of Immigration. International Migration Review 31: 826-74. [CrossRef] [PubMed]

Amin, Camron Michael. 2002. The Making of the Modern Iranian Woman: Gender, State Policy, and Popular Culture. Gainesville: University of Florida Press.

Amin, Camron Michael. 2014. An Iranian in New York: Abbas Masudi's Description of the Non-Iran on the Eve of the Cold War. In Rethinking Iranian Nationalism and Modernity. Edited by Kamran Scot Aghaie and Afshin Marashi. Austin: University of Texas Press, pp. 161-78.

An Empty Place at the Table. 2005. Susan Yasipour. Available online: http://lycofs01.lycoming.edu/ estomin/ violence/susan.htm (accessed on 18 March 2016).

Anderson, Judge Dudley N. 2001. Commonwealth of Pennsylvania vs. Brian Yasipour, No. 01-11,465 Competency Determination: Opinion and Order. Willimasport: Commonwealth of Pennsylvania, November 6.

Anderson, Judge Dudley N. 2002. Commonwealth of Pennsylvania vs. Brian Yasipour, Sr. Defendant. No. 01-11.465. Pre-Trial Motion. Opinion and Order. Willimasport: Commonwealth of Pennsylvania, November 22.

Anderson, Judge Dudley N. 2005. Commonwealth of Pennsylvania vs. Brian Yasipour, Sr. Defendant. No. 01-11.465. Motion for Continuance. Opinion and Order. Willimasport: Commonwealth of Pennsylvania, August 3.

Anderson, Judge Dudley N. 2006. Commonwealth of Pennsylvania vs. Brian Yasipour, No. 01-11,465 Post Sentence Motion: Opinion and Order. Willimasport: Commonwealth of Pennsylvania, August 21.

Anderson, Judge Dudley N. 2010. Interview with Judge Dudley Anderson. Williamsport, PA, USA, January 25.

Baker, Beth. 2016. Regime. In Keywords of Mobility. Edited by Noel B. Salazar and Kiran Jayaram. New York: Bergahn, pp. 152-70.

Bedir, Murteza. 2004. Fikih to Law: Secularization through Curriculum. Islamic Law and Society 11: 378-401. [CrossRef]

Bonfanti, Sara. 2016. Dislocating Pujabiyat: Gender Mobilities among Indian Diasporas in Italy. In Bounded Mobilities: Ethnographic Perspectives on Social Hiarchies and Global Inequalities. Bielefeld: Transcipt Verlag, pp. 183-208.

Brown, Richard D. 2003. Microhistory and the Post-Modern Challenge. Journal of the Early Republic 23: 1-20. [CrossRef]

Chaichian, Mohammad A. 1997. First Generation Iranian Immigrants and the Question of Cultural Identity: The Case of Iowa. The International Migration Review 31: 612-27. [CrossRef]

Code Switch. 2017. Interview with Neda Maghbouleh, Author of the Upcoming Book: The Limits of Whiteness: Iranian Americans and the Everyday Politics of Race. Redwood City: Stanford University Press, April 19. Available online: http:/ / www.npr.org/podcasts/510312/codeswitch (accessed on 19 July 2017). 
Demian, Melissa. 2008. Fictions of Intention in the "Cultural Defense". American Anthropologist 110: 432-42. [CrossRef]

D'hondt, Sigurd. 2010. The Cultural Defense as Courtroom Drama: The Enactment of Identity, Sameness, and Difference in Criminal Trial Discourse. Law E Social Inquiry 35: 67-98.

Elahi, Babak. 2006. Translating the Self: Language and Identity in Iranian-American Women's Memoirs. Iranian Studies 39: 461-80. [CrossRef]

Eshaqi, Mohammad. 2001. The Punishment of Mothers and Fathers for the Crime of Killing a Child: Article 220 of the Islamic Penal Code Mojazāt-e Pedar va Mādar dar Jorm-e Koshtan-i Farzand: Māddeh-e 220 Qānun-i Mojāzāt-e Eslāmi. Tehran: Safir-e Sobh.

Farr, Stephanie. 2006a. Prosecution: Yasipour 'Faking'. Williamsport Sun-Gazette, March 7, Cited by Quinn on Forums for Justice. (See FFJ).

Farr, Stephanie. 2006b. Yasipour Trial Set to Resume. Williamsport Sun-Gazette, March 13.

Farr, Stephanie. 2006c. Yasipour's Sons Testify at His Trial. Williamsport Sun-Gazette, March 14.

Farr, Stephanie. 2006d. Guilty but Mentally Ill: Judge Develops His Own Theory of Why Yasipour Slew His Daughter. Williamsport Sun-Gazette, March 27.

Farr, Stephanie. 2014. Author Telephone Interview with Stephanie Farr. Berkley, MI, USA, Recorded 20 May.

Fata, Soraya, and Raha Rafii. 2003. Iran Census Report: Strength in Numbers: The Relative Concentration of Iranian Americans Across the United States. Washington: National Iranian American Council, Available online: https:/ / www.niacouncil.org/docs/irancensus.pdf (accessed on 27 July 2017).

FFJ. 2006. Forums for Justice. Susan Yasipour. March 7-April 19. Available online: http:/ /www.forumsforjustice. org/forums/showthread.php?6760-Susan-Yasipour (accessed on 27 July 2017).

Findlen, Paula. 2003. The Singularization of Historytion of Historytory esMicrohistory within the Postmodern State of Knowledge. Journal of Social History 36: 701-35.

Findlen, Paula. 2005. Two Cultures of Scholarship? Isis 96: 230-37. [CrossRef] [PubMed]

Ginzburg, Carlo. 1980. The Cheese and the Worms: The Cosmos of a Sixteenth Century Miller. Translated by John, and Ann Tedeschi. Baltimore: John Hopkins Press and Routledge, Kegan \& Paul.

Ginzburg, Carlo. 2005. Latitude, and the Bible: An Experiment in Microhistory. Critical Inquiry 31: 665-83.

Ginzburg, Carlo, John Tedeschi, and Anne C. Tedeschi. 1993. Microhistory: Two or Three Things That I Know About It. Critical Inquiry 20: 10-35. [CrossRef]

Goel, Rashmi. 2004. Can I Call Kimura Crazy? Ethical Tensions in the Cultural Defense. Seattle Journal for Social Justice 3: 443-64.

Gualtieri, Sarah. 2009. Between Arab and White: Race and Ethnicity in the Early Syrian American Diaspora. Berkeley: The University of California Press.

Hackl, Andreas, Julia Sophia Schwarz, Miriam Gutekunst, and Sabina Leoncini. 2016. Bounded Mobilities: An Introduction. In Bounded Mobilities: Ethnographic Perspectives on Social Hiarchies and Global Inequalities. Edited by Miriam Gutekunst, Andreas Hackl, Sabina Leoncini, Julia Sophia Schwarz and Irane Götz. Bielefeld: Transcipt Verlag, pp. 19-34.

Haeri, Shahla. 2014. Law of Desire: Temporary Marriage in Shi'i Iran, rev. ed. Syracuse: Syracuse University Press.

Hoffman, Katherine E. 2010. Berber Law by French Means: Customary Courts in the Moroccan Hinterlands, 1930-1956. Comparative Studies in Society and History 52: 851-80. [CrossRef]

Jennings, Ronald C. 1999. Studies on Ottoman Social History in the Sixteenth and Seventeenth Centuries: Women, Zimmis, and Sharia Courts in Kayseri, Cyprus and Trabzon. Istanbul: ISIS Press.

Karim, Persis M., and Nasrin Rahimieh. 2008. Introduction: Writing Iranian Americans into the American Literature Canon. MELUS 33: 7-16. [CrossRef]

Kashani-Sabet, Firoozeh. 2011. Conceiving Citizens: Women and the Politics of Motherhood in Iran. Oxford: Oxford University Press.

Kia, Mehrdad. 1994. Constitutionalism, Economic Modernization and Islam in the Writings of Mirza Yusef Khan Mostashar od-Dowle. Middle Eastern Studies 30: 751-77. [CrossRef]

King, Nancy J., David A. Soulé, Sara Steen, and Robert R. Weidner. 2005. When Process Affects Punishment: Differences in Sentences after Guilty Plea, Bench Trial, and Jury Trial in Five Guidelines States. Columbia Law Review 105: 959-1009.

Lamoreaux, Naomi R. 2006. Rethinking Microhistory: A Comment. Journal of the Early Republic 26: 555-61. [CrossRef] 
Lapore, Jill. 2001. Historians Who Love Too Much: Reflections on Microhistory and Biography. The Journal of American History 88: 129-44. [CrossRef]

Lehti, Martti, Juha Kääriäinen, and Janne Kivivuori. 2012. The Declining Number of Child Homicides in Finland, 1960-2009. Homicide Studies 16: 2-22. [CrossRef]

Levine, Kay L. 2003. Negotiating the Boundaries of Crime and Culture: A Sociolegal Perspective on Cultural Defense Strategies. Law and Social Inquiry 28: 39-86. [CrossRef]

Locke, Robert. 2003. Islam's Love-Hate Relationship with Homosexuality. The Front Page. January 23. Available online: http: / / archive.frontpagemag.com/readArticle.aspx?ARTID=20145 (accessed on 15 June 2017).

Malek, Amy. 2006. Memoir as Iranian Exile Cultural Production: A Case Study of Marjane Satrapi's "Persepolis" Series. Iranian Studies 39: 353-80. [CrossRef]

Mariano, Timothy, Heng Choon (Oliver) Chan, and Wade C. Myers. 2014. Toward a More Holistic Understanding of Filicide: A Multidisciplinary Analysis of 32 Years of U.S. 2014 Arrest Data. Forensic Science International 236: 46-53. [CrossRef] [PubMed]

Miele, William, and Nicole Spring. 2010. Author Interview with William Miele and Nicole Spring. Williamsport, PA, USA, June 10.

Mir-Hosseini, Ziba, and Kim Longinatto. 2003. Divorce Iranian Style, Video recording. Film by Ziba Mir-Hosseini and Kim Longinatto, 1998; New York: Women Make Movies.

Mobasher, Mohsen M. 2012. Iranians in Texas: Migration, Politics, and Ethnic Identity. Austin: University of Texas Press.

Modarres, Ali. 1998. Settlement Patterns of Iranians in the United States. 1998. Iranian Studies 31: 31-49. [CrossRef]

Mostofi, Nilou. 2003. Who We Are: The Perplexity of Iranian-American Identity. The Sociological Quarterly 44: 681-703. [CrossRef]

Osanloo, Arzoo. 2006a. The Measure of Mercy: Islamic Justice, Sovereign Power, and Human Rights in Iran. Cultural Anthropology 21: 575-79. [CrossRef]

Osanloo, Arzoo. 2006b. Islamico-Civil 'Rights-Talk:' Women, Subjectivity, and Law in Iranian Family Court. American Ethnologist 33: 190-209. [CrossRef]

Parsā-ā lipur, Keyārash. 2009. Qatl-e Farzand: Pedar Ta 'zir, Mādar E'dām, The Murder of a Child: The Father Ta'zir, the Mother, Execution. Radiyo Zamāmeh. October 28. Available online: http://zamaaneh.com/ humanrights /2009/10/print_post_446.html (accessed on 27 May 2014).

Peltonen, Matti. 2001. Clues, Margins, and Monads: The Micro-Macro Link in Historical Research. History and Theory 40: 347-59. [CrossRef]

Pierce, Leslie. 1999. Orality, Honor, and Representation in the Ottoman Court of 'Aintab. In Women in the Medieval Islamic World. Edited by Gavin R. G. Hambly. New York: St. Martin's Press, pp. 347-59.

Public Affairs Alliance of Iranian Americans. 2014. Iranian-Americans: Immigration and Assimilation. Washington: Public Affairs Alliance of Iranian Americans, Available online: http:/ / paaia.org/wp-content/uploads / 2017/04/iranian-americans-immigration-and-assimilation.pdf (accessed on 15 June 2017).

Putnam, Lara. 2006. To Study the Fragments/Whole: Microhistory and the Atlantic World. Journal of Social History 39: 615-30. [CrossRef]

Rowe, G.S. 1991. Infanticide, Its Judicial Resolution, and Criminal code Revision in Early Pennsylvania. Proceedings of the American Philosophical Society 135: 208-10.

Schiller, Nina Glick, and Noel B Salazar. 2013. Regimes of Mobility across the Globe. Journal of Ethnic and Migration Studies 39: 183-200. [CrossRef]

Scott, Joan Wallach. 1999. Gender and the Politics of History, rev. ed. New York: Columbia University Press.

Sharafi, Mitra. 2008. Justice in Many Rooms since Galanter: De-Romanticizing Legal Pluralism through the Cultural Defense. Law and Contemporary Problems 71: 139-46. [CrossRef]

Spannus, Nathan. 2013. The Decline of the $\bar{A} k h \bar{u} n d$ and the Transformation of Islamic Law under the Russian Empire. Islamic Law and Society 20: 202-41. [CrossRef]

Superior Court of Pennsylvania. 2008. Commonwealth of Pennsylvania, Appellee v. Brian Yasipour, Sr. Appellant. Decided: September 17. Available online: http:/ / caselaw.findlaw.com/pa-superior-court/1438863.html (accessed on 19 July 2017).

Tehranian, John. 2008. Selective Racialization: Middle-Eastern American Identity and the Faustian Pact with Whiteness. Connecticut Law Review 40: 1201. Available online: http:/ /heinonline.org/HOL/LandingPage? handle=hein.journals $/$ conlr40\&div=42\&id=\&page $=($ accessed on 11 June 2017). 
Tehranian, John. 2009. Whitewashed: America's Invisible Middle Eastern Minority. New York: NYU University Press. Tomer-Fishman, Tamar. 2010. “Cultural Defense," “Cultural Offense," or no Culture at All?: An Empirical Examination of Israeli Judicial Decisions in Cultural Conflict Criminal Cases and of the Factors Affecting Them. The Journal of Criminal Law and Criminology 100: 475-522.

Tucker, Judith. 1998. In the House of the Law: Gender and Islamic Law in Ottoman Syria and Palestine. Berkeley: University of California Press.

TY. 2006. Transcript of Commonwealth of Pennsylvania vs. Brian Yasipour. No. 01-11,465, Trial, Williamsport, PA, USA. March 6, 7, 13, 14, 21 and 22.

Volpp, Leti. 2006. Disappearing Acts: On Gendered Violence, Pathological Cultures, and Civil Society. PMLA 121: 1631-38.

Volpp, Leti. 2012. Imaginings of Space in Immigration Law. Law, Culture and the Humanities 9: 457-74. [CrossRef] Walters, Mary C., and Tomas R. Jimenez. 2005. Assessing Immigrant Assimilation: New Empirical and Theoretical Challenges. Annual Review of Sociology 31: 105-25. Available online: http:/ / nrs.harvard.edu/urn-3:HUL. InstRepost:3203280 (accessed on 29 May 2015). [CrossRef]

Wheeler, Marcy. 2008. How Noninstitutionalized Media Change the Relationship between the Public and Media Coverage of Trials. Law and Contemporary Problems 71: 135-53.

Williamsport Sun-Gazette. 2014. Man Jailed for Murder Dead at 64. Williamsport Sun-Gazette, August 5.

WNEP. 2006. Man Guilty of Killing Daughter. Available online: http:/ / wnep.com (accessed on 1 June 2006).

Yasipour, Brian. 2010. Author interview with Brian Yasipour. Somerset County, PA, USA: Pennsylvania State Correctional Institution-Laurel Highlands, June 11.

Ze'evi, Dror. 1998. The Use of Ottoman Sharia Court Records as a Source for Middle Eastern Social History: A Reappraisal. Islamic Law and Society 5: 35-56. [CrossRef]

Zia-Ebrahimi, Reza. 2016. The Emergence of Iranian Nationalism: Race and the Politics of Dislocation. New York: Columbia University Press.

(C) 2017 by the author. Licensee MDPI, Basel, Switzerland. This article is an open access article distributed under the terms and conditions of the Creative Commons Attribution (CC BY) license (http:/ / creativecommons.org/licenses/by/4.0/). 